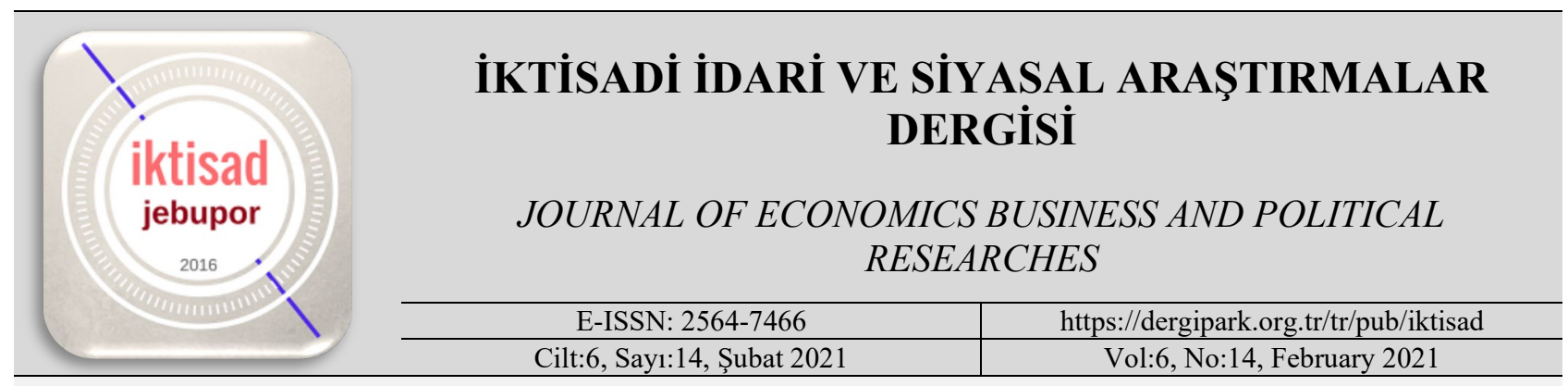

\title{
Örgütsel Özdeşleşme ve Örgütsel Sinizm İlişkisi: Pamukkale Üniversitesindeki İdari Personele Yönelik Bir Araştırma
}

\section{Organizational Identification and Organizational Cynicism Relationship: A Research on Administrative Personnel in Pamukkale University}

DOI: https://doi.org/10.25204/iktisad.836186

Celaleddin SERINKAN*

Muharrem TÜLÜ**

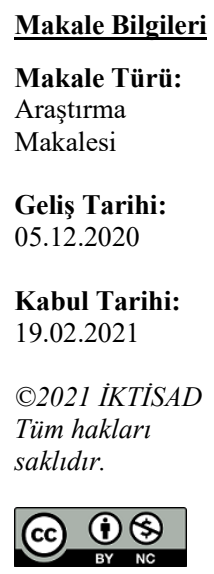

Örgütsel özdeşleşme ve örgütsel sinizm, kurumlar açısından önemli araştırma konularl olmaya başlamıştır. Örgütsel özdeşleşmenin kurumlar için verim arttırıcı faydaları olduğu kabul edilirken, örgütsel sinizmin verim düşürücü olduğu değerlendirilmektedir. Bu çalışmanın temel amacl, örgütsel özdeşleşme ile örgütsel sinizm arasındaki ilişkiyi belirlemektir. Diğer bir amaç ise, Pamukkale Üniversitesinin Kınıkl Yerleşkesindeki Fakültelerde görev yapan idari personelin örgütsel özdeşleşme ve örgüt sinizm düzeylerini incelemektir. Çalışmanın diğer bir amacı da idari personelin demografik özellikleri açısından gruplar arasında farklılıkların olup olmadı̆̆ını tespit etmektir. Bu amaca ulaşmak için idari personele anket yöntemi uygulanmıştır. Araştırmanın örneklemi, 174 veri setinden oluşmaktadır. Araştırma sonuçlarına göre, örgütsel özdeşleşme ve örgütsel sinizm arasında negatif ve anlamlı bir ilişki tespit edilmiştir. Örgütsel özdeşleşme açısından cevaplayıcıların demografik özelliklerine göre farklılıklar tespit edilememiştir. Ancak örgütsel sinizm açısından gruplar arasında yaş, eğitim ve maaş düşüncelerine göre bazı anlamlı farklılıklar bulunmuştur.

Anahtar Kelimeler: Örgütsel özdeşleşme, örgütsel sinizm, Pamukkale Üniversitesi, idari personel.

\begin{abstract}
Organizational identification and organizational cynicism have become important research topics for institutions. While it is accepted that organizational identification has efficiency improvement benefits for institutions, organizational cynicism is considered to be reducing the productivity. The main purpose of this study is to determine the relationship between organizational identification and organizational cynicism. Another purpose is to examine the organizational identification and organizational cynicism levels of the administrative staff working in the Faculties of Pamukkale University's Kinikl Campus. In addition to these aims of the study, another aim is to determine whether there are differences between the groups in terms of the demographic characteristics of the administrative staff. In order to achieve these goals, a survey method was applied to administrative staff. The sample of the study consists of 174 data sets. According to the results of the research, a negative and significant relationship was found between organizational identification and organizational cynicism. In terms of organizational identification, there weren't found any differences according to the demographic characteristics of the respondents. However, in terms of organizational cynicism, there were found some significant differences according to the age, education and salary opinions of the groups.
\end{abstract}

Keywords: Organizational identification, organizational cynicism, Pamukkale University, administrative staff.

Atıf/ to Cite (APA): Serinkan, C. \& Tülü, M. (2021). Örgütsel Özdeşleşme ve Örgütsel Sinizm İlişkisi: Pamukkale Üniversitesindeki İdari Personele Yönelik Bir Araştırma. İktisadi İdari ve Siyasal Araștırmalar Dergisi, 6(14), 48-70.

*ORCID Prof. Dr., Pamukkale Üniversitesi, İİBF, İşletme Bölümü, cserinkan@pau.edu.tr

** ORCID Yüksek Lisans Öğrencisi, Pamukkale Üniversitesi, SBE, Yönetim ve Organizasyon Programı, mtulu14@posta.pau.edu.tr 


\section{EXTENDED ABSTRACT}

\section{Background}

Organizations desire to benefit from their employees much more. In the situation that aims of the institution and the employees' own aims integrate and get harmony, the phenomenon of identification is lived. The identified employees spend more effort by thinking that activities being for the benefit of the organization also become for the benefit of themselves. On the contrary, when the employees have negative manner towards their organizations and they behave depreciatively towards the organization or they believe the organization behaves hypocritically and is far from honesty, the cynicism phenomenon is generated. In the institutions where the cynicism level is high, uneasiness comes out and the employees do not wish to work in that institution.

\section{Research Purpose}

The main aim of this study is to determine the relationship between organizational identification and organizational cynicism. To do that, it is examined the organizational identification and the organizational cynicism levels of administrative personnel serving in faculties in the Kınıklı settlement of Pamukkale University. While this research is conducted, it is also targeted to detect if there is any difference among groups in terms of demographic properties of administrative personnel. In Turkey the studies about organizational identification and organizational cynicism, towards the public sector, especially in the university area, are very limited. In universities, determining the organizational identification levels of the personnel serving in administrative section is important because in the institutions where organizational identification is provided, morale and motivations of employees happen better and significant increases in their organizational performance and efficiency levels are seen. On the other hand, it is expected that the administrative personnel act cynic behaviors and attitudes less often. For these reasons, administrative personnel are included in the scope of the research.

\section{Methodology}

This study is a descriptive research. In the research the sampling method was preferred, and the survey method was applied to the personnel willingly attending to the research. In this research 11 hypotheses are formed. Five of these hypotheses assert that the organizational identification differs according to gender, marital status, age, education and income considerations. Other five hypotheses put forward that organizational cynicism differs according to gender, marital status, age, education and income considerations. The last hypothesis of this study has the aim of proving that there is a positive relation between organizational identification and organizational cynicism. The research population comprises the personnel serving in 12 faculties and in the rectorate taking place in the Kınıklı settlement of Pamukkale University. In the result of the survey method applied, 174 valid data sets were reached. In this study, the reliability analysis, the factor analysis for the validity analysis of scales, t-test and ANOVA test for reaching hypothesis findings, the correlation of organizational identification and organizational cynicism and finally the quantitative analyses towards regression findings of organizational identification and organizational cynicism dimensions are made.

\section{Conclusions}

According to the result of the research, a negative and meaningful relationship is available between organizational identification and organizational cynicism. This relation is partly in medium strength. In this situation it can be said that as far as organizational identification increases, organizational cynicism decreases. In the research, any meaningful difference between organizational identification and gender, marital status, age, education and income consideration could not find out. In organizational cynicism hypotheses it is detected that cynicism does not differ meaningfully according to age and marital status. It was proved that there is a negative relation between organizational identification and organizational cynicism. Moreover, meaningful differences among age, education and income consideration are determined. On the other hand, in the regression analysis made towards how organizational cynicism affects organizational identification, it is found out cognitive dimension affected organizational cynicism by $44 \%$. Finally, limitedness of the research is that the study is conducted towards administrative personnel serving in faculties in a settlement of a public university. It suggested to researchers, who wish to do further studies, that widening the scope of research as well as including academics would give more accurate results. 


\section{GíRiş}

Günümüzün çalışma koşullarında insanın varlığı ön plandadır. Çalışanın işine gösterdiği çaba ile işten elde ettiği çıtılarının doğru orantılı olduğu varsayılmaktadır. Bu bağlamda personelin varlığ 1 kurumlar için önemli değerler olarak görülmektedir. İş hayatında personelin kurumu ile birliktelik oluşturması sonucunda örgütsel özdeşleşme oluşmaktadır. Kurumun başarısı ile gururlanan, başarısızlığı ile de hüzünlenen bir personel profiline sahip olmak, özdeşleşme bakımından önemlidir. Özdeşleşen çalışanlar, kurumları için daha fazla çaba gösterip kurumlarına bağlılık gösterebilmektedirler. Diğer yandan, çalışma hayatı içinde kurumlarda personel ile kurum arasında birtakım uyumsuzluklar da ortaya çıkabilmektedir. Bu uyumsuzluklara çalışanlar, çeşitli şekilde tepki göstererek kurumunu küçümseyici tavırlar sergileyebilmektedirler. Çalıştıkları iş yerlerine değişik sebeplerle olumsuz tutum ve davranışlar içinde olan kişilerin gösterdikleri bu tür davranışlara örgütsel sinizm denilmektedir. Sinik olarak tabir edilen çalışanlar, kurumlarını sabote ederek kendi çalışma performanslarını düşürdükleri gibi etraflarındaki kişileri de etkileyerek insanların kurumda gösterdikleri verimliliği de etkileyebilmektedirler.

Örgütsel yaşamın akıcılığında değişime ayak uydurmak gerekmektedir. Bu değişimlere karşı kendini geliştiremeyen kurumlar ile personel arasında kopukluk olmaktadır. Bu nedenle çalışanlar kurumuna yönelik özdeşleşememe ve sinik davranışlar sergileme eğilimine yönelmektedirler. Personeline değer veren kurumlarda, çalışanların kurumlarıyla özdeşleşmesi daha kolay olabilmektedir. Kurumlarıyla özdeşleşen çalışanların motivasyonlarının yüksek düzeyde olması nedeniyle sinik duygu, düşünce ve davranışlara sahip olmayacakları söylenebilir. Bu bağlamda, kamu kurumları açısından da örgütsel özdeşleşme ve örgütsel sinizm önemli yer teşkil etmektedir.

Kamu kurumlarının önemli unsurlarından olan üniversiteler gerek eğitim ve öğretimde gerekse de araştırma ve geliştirmede oldukça önemli rollere sahiptirler. Akademik personelin verimliliklerinin ve performanslarının arkasında ve onların idari işlerinin iyi bir şekilde gerçekleştirilmesinde idari personelin önemli rolleri bulunmaktadır. Bu idari personelin çalıştıkları kurumlarıyla özdeş halde olmaları büyük önem taşımaktadır. Üniversitesinde bulunmaktan memnun olan, kendisinin görevlerini tam anlamıyla yapmasının yanı sıra mevcut potansiyelini kurumu için kullanan idari personel, kurumuyla özdeş olduğu ve kurumuna bağlı hale geldiği söylenebilir. $\mathrm{Bu}$ niteliklere sahip olan üniversite personelinin sinik davranış ve tutumlara itibar etmeyeceği belirtilebilir.

$\mathrm{Bu}$ çalışmanın planlanması aşamasında yapılan literatür araştırmasında, üniversitelerde görev yapan idari personel ile ilgili örgütsel özdeşleşme ve örgütsel sinizm konularının yeterli düzeyde araştırılmadığ tespit edilmiştir. Bu nedenle üniversitede görev yapan idari personelin bu konulardaki durumlarının belirlenmesi için araştırma konusu olarak belirlenmiştir. Araştırmanın problemi, idari personel kendi kurumlarıyla özdeş hale gelmiş midir ve kurumlarına karşı sinik davranışlara sahip midirler? Örgütsel özdeşleşmenin olduğu yerde, örgütsel sinizm davranışı azalmakta mıdır?

Bu çalışmada, öncelikle örgütsel özdeşleşme ve örgütsel sinizm kavramları açıklandıktan sonra araştırma kısmında iki kavram arasında ilişkinin olup olmadığına bakılmıştır. Araştırmanın örneklemini de Pamukkale Üniversitesinin Kınıklı Yerleşkesindeki fakültelerde görev yapan idari personel oluşturmaktadır.

\section{TEORIK ÇERÇEVE}

Çalışmanın teorik konusu olan örgütsel özdeşleşme ve örgütsel sinizm kavramları ile ilgili detaylı bilgiler aşağıda belirtilmektedir. 


\section{1. Örgütsel Özdeşleşme}

Örgütsel özdeşleşme çalışmaları, örgütsel davranış ve yönetim alanları bakımından ilgilenilen ana konulardan biri haline gelmiştir. Bunun nedeni örgütsel özdeşleşmenin, örgüt ile çalışan arasındaki temel bağın oluşmasını, gelişmesini ya da bozulmasına yönelik nedenleri tahmin eden ve açıklayan önemli bir konu olmasıdır (Edwards, 2005: 207). Örgütsel özdeşleşme konusu üzerine yapılan çalışmalar incelendiğinde, bu kavramın Sosyal Kimlik Kuramı ile açıklandığı görülmektedir (Tak ve Çiftçioğlu, 2009: 102; Cheney ve Tompkins, 1987: 5).

Sosyal Kimlik Kuramı (Social Identity Theory) 1970'lerin ortalarında Henri Tajfel ve John Turner tarafından geliştirilmiştir (Demirtaş, 2003: 124). Tajfel'e (1982: 24) göre sosyal kimlik, bireyin benliğinin bir sosyal gruba yönelik üyelik bilgisiyle, bu grubun üyesi olmaya dair taşıdığı değerden ve duygusal bağlılıktan kaynaklandığı vurgulanmaktadır. Pratt ve Rafaeli'e (1997: 863) göre sosyal kimliklerin, bireylerin “ben kimim?” sorusuna yanıt vermelerine yardımcı olacağını ve mensubu oldukları sosyal grupları tasvir etmelerine imkân sağladığı belirtilmektedir. Walsh ve Gordon'a (2008: 48) göre ise sosyal kimlik, bireyin kendisi için nasıl ve neden bir iş kimliği oluşturması gerektiğini açıklamaktadır. Billig ve Tajfel'e (1973: 27-28) göre, birey sosyal yaşamında ilişkide bulunduğu sosyal grupları "biz ve onlar" olarak kategorize etmektedir. Yazarlara göre, birey benimsediği grubu, diğer gruplardan üstün tutmaktadır. Tolman (1943: 143) da bireyin özdeşleştiği grup veya örgüt ile kendisini bir hissetmesi, örgütün hedeflerini kendi hedefleri gibi, örgütün başarılarını veya başarısızlıklarını da kendi başarısı ya da başarısızlığı olarak kabul ettiğini savunmaktadır.

$\mathrm{Bu}$ bakış açısıyla denilebilir ki, sosyal kimlik kuramı örgütsel özdeşleşmenin psikolojik önemine 1şı1k tutmaktadır (Kağıtçıbaşı ve Cemalcılar, 2019: 263). Van Knippenberg ve Sleebos (2006: 574) da aynı şekilde, örgütsel özdeşleşmenin birey ve örgüt arasında psikolojik olarak birlik olma durumunu ifade ettiğini savunmaktadırlar. Rousseau'ya (1998: 217) göre ise örgütsel özdeşleşme, bireyin kendisini daha büyük bir örgütün parçası olarak algıladığı psikolojik bir durum olarak tarif edilmektedir.

Bhattacharya ve Elsbach'a (2002: 28) göre özdeşleşme, bireyin örgütü algılamasından dolayı değil, bireyin kendisini algılama amacından kaynaklanmaktadır. Sammarra ve Biggiero'a (2001: 68) göre ise, örgütsel özdeşleşmeyle birey, bilişsel olarak çevresini algılayıp yorumlayarak bir anlam süreci yaşamaktadır. Bu anlam sürecini, Ashforth vd. (2008: 333) bireyin "örgütümle kendimi nasıl algılıyorum?" sorusuyla ilgili olduğunu iddia etmektedirler.

Ashforth ve Mael (1989: 34) örgütsel özdeşleşmeyi, örgütün amaçları ile bireyin amaçlarının bütünleşme ve uyumlaşma süreci olarak tanımlamaktadırlar. Diğer yandan Dutton vd. (1994: 242) örgütsel özdeşleşmeyi, örgüt üyelerinin örgüt için kullanılan tanımları kendileri için de kullanmaya başladıklarında oluşan psikolojik bağlanma durumu olduğunu savunmaktadırlar. Hatta Whetten ve Godfrey (1998: 179) tarafından örgütsel özdeşlemenin tanımlanmasının iki yolu olabileceği öne sürülmektedir. Onlara göre birincisi, bireyin kendi kimliğiyle örgütün değerleri ve inançlarının benzerlik yönünden özdeşleşmesi, ikincisi ise bireyin değer ve inançlarının değişerek örgütün değerleriyle uyumlu hale gelmesidir.

Van Knippenberg ve Van Schie (2000: 138) tarafından örgütsel özdeşleşme, bireyin kendisini sosyal sınıflandırmaların bir üyesi olarak tanımlaması ve bu sınıflandırmadaki örgütün tipik özelliklerini kendisine atfetmesidir. Diğer yandan Dutton vd. (1994: 239) örgütsel özdeşleşmeyi iki şekilde açıklamaktadırlar. Onlara göre birincisi, bireyin örgütte kendi varlığına göre yaptı̆̆ tanımla, ikincisi ise örgüt için yaptığı tanımın benzerliğine dair inançlarıdır. Yine Ashforth vd. (2008: 329) göre örgütsel özdeşleşme, bireyin kendi kendini tanımlarken kullandığı ifadelerle oluştuğunu iddia etmektedirler.

Van Dick ve Wagner (2002: 132) örgütsel özdeşleşmenin odak noktalarını dört bakış açısıyla açıklamaktadırlar. Birincisi, bireyin kendi kariyeri ile özdeşleşmesi, ikincisi bireyin çalışma 
bölümüyle veya grubuyla özdeşleşmesi, üçüncüsü örgütün bütünüyle özdeşleşmesi ve son olarak ise mesleğiyle, meslek gruplarıyla veya sendika gruplarıyla özdeşleşmesi olarak açıklanabilir. Oysa Mael ve Ashforth (1992: 106) örgütsel özdeşleşmeyi meslekle veya işle özdeşleşme durumundan ayırmaktadırlar. Onlara göre meslekle veya işle özdeşleşme, bireyin yaptığı iş bakımından kendini değerlendirdiği husus iken, örgütsel özdeşleşme ise bireyin örgüt açısından kendini tanımladığ1 husustur.

Levinson'a (1965: 373) göre örgütsel yaşamda çalışanlar, bireysel özellikleri veya demografik özellikleriyle değil, örgütleriyle özdeşleşmektedirler. Mael ve Ashforth'a (1995: 312) göre, örgüt ile özdeşleşen birey, örgütün özelliklerini kişileştirerek kendisini örgütün kişiliğiymiş gibi anlamlandırdığını savunmaktadırlar. Diğer bir tabirle Kreiner ve Ashforth'ın (2004: 2) deyimiyle örgüt üyesinin kendisini en azından örgütün temsil ettiği düşünülen terimlerle tanımlaması ile örgütsel özdeşleşme gerçekleşecektir. Dolayısıyla Ravishankar ve Pan'a (2008: 223) göre, örgüt üyesinin örgüt kimliğini kendi kimliği gibi algılayıp tanımlamadığında, örgütsel özdeşleşme gerçekleşmezken örgüt kimliğini kendi kimliği gibi algılayıp tanımlanmasıyla örgütsel özdeşleşme meydana gelmektedir.

Rotondi'ye (1975: 892) göre örgütsel özdeşleşme sonucunda bireyler, örgütün amaçlarına bağl1lık duyacaklar ve örgütsel amaçları gerçekleştirmek için çaba sarf edeceklerdir. Çalışanlar örgütle özdeşleştiğinde, örgütün yararına olan faaliyetlerin kendi yararlarına da olacağını düşüneceklerdir (Dutton vd., 1994: 255). Cheney’e (1983: 343) göre örgütsel özdeşleşme üzerine yapılan çalışmalarda; motivasyon, iş tatmini, iş performansı, bireysel karar alma, rol çatışması, personel ile ilişkiler ve hizmet süresi gibi konuların örgütsel özdeşleşmeyle ilişkili olduğu belirtilmektedir. Aynı zamanda örgütüyle özdeşleşen çalışanlarda; işe yönelik bir anlam, kurumuna karşı aidiyet duygusu ve örgüte karşı bilinçlerinin geliştiği öne sürülmektedir (Kreiner ve Ashforth, 2004: 2). Kurumuyla yüksek düzeyde özdeşleşen örgüt üyeleri sayesinde, örgüt içi iş birliğinin daha iyi sağlanması ve örgütsel vatandaşlığın tesis edilmesi mümkün olabilmekte (Dutton vd., 1994: 240) ve çıkar ilişkilerinde ise örgütün menfaatine yönelik kararlar alınabilmektedir (Edwards, 2005: 207).

\section{2. Örgütsel Sinizm}

Sinizm kavramının kökeni araştırıldığında; ilk ortaya atan kişinin İ.Ö. 444'de doğup yaşamış ve İ.Ö. 368 'te ölmüş olan Antisthenes olduğu ifade edilmektedir. Antisthenes, ilk önce Gorgias'ın öğrencisi olmuş, daha sonra Sokrates'in öğretileri ile Sokrates'in hayranı ve öğrencisi olmuştur. Kynosargues Gimnazyumu'nda kendi okulunu kuran Antisthenes'in öğretisinin isminin bu okulun adından geldiği düşünülmektedir. Sinizm kavramının İngilizcesi "Cynicism" olarak kullanılmaktadır. Sinizm kavramının kökeni ile ilgili diğer bir görüş ise "Kynik" kelimesinin "Kyon"dan türediği ileri sürülerek Kyon'un Yunancada köpeksi, köpek gibi olan, köpeğe benzeyen ve köpek tutumlarına sahip olma anlamı taşıdığı belirtilmektedir (Gökberk, 1993: 52).

Kinikler için en önemli şey, kendine yeter olma ve gerek iç arzulardan gerekse de diş dünyadan bağımsız ve de özgür olmaktır. Kinikler dini, devleti, toplumu ve aile kurumunu insanın özgürlüğünü kisitlayan, engel olan unsurlar olarak görüp bunlara hiçbir önem ve değer atfetmemeyi tercih etmektedirler. Sinizme asıl ününü kazandıran ise Sinoplu Diogenes olmuştur. Diogenes, var olan bütün kültürel değerleri reddedip insanlığın ilkel haline geri dönmesini ve gerçek anlamı ile insanın hayvan gibi "köpeksi" bir yaşam sürmesi gerektiğini ileri sürmüştür. Diogenes'in çıplak zeminde yattığı, bulduğu her şeyi yediği, bir çocuğun eliyle su içtiğini görünce bardağını kullanmayı bıraktığını, dilenci tarzında dolaştığını, Atina'nın Kybele mabedinin avlusunda bir fiçı içinde yaşadığını, İskender'in Korint'e geldiğinde İskender ile karşılaşmasında kendisini "Ben, köpek Diogenes'im" şeklinde tanıttığını ve İskender'in kendisinden bir isteği olup olmadığı sorusuna "Gölge etme, başka ihsan istemem" sözü ile cevap verdiği kabul edilmektedir (Arslan, 2006: 164$165)$. 
Sinizm kavramının ilk ortaya çıkmasında bilgelik ve erdem mülahazaları ön plandayken günümüze geldiğimizde bu kavramın olumsuzluk içeren bir kelime olduğu kabul edilmektedir. Bununla birlikte iş yaşamında yaşanılan adaletsizliklerin, politik davranışların, çatışmaların, stresin ve işe yönelik motivasyon ile güvenin azalması örgütsel sinizmi meydana getirmektedir (Gündüz, 2017: 141). Sinizm günlük yaşamda da yaygın şekilde görünmekte ve insanların diğer insanlara ve örgütlere güvenmedikleri bir faktör olarak beyan edilmektedir (Peng ve Zhou, 2009: 863).

Abraham (2000: 269) örgütsel sinizmi, dürüstlükten yoksun olan, örgütte çalışanın örgüte karş1 olumsuz duygusal tepkiler beslemesi ve eleştirel davranışlarda bulunması olarak ifade etmektedir. Brandes vd. ise (2008: 235) sinizmi, örgütte diğerlerine karşı bir hoşlanmama ve güvenmeme durumunu ifade ettiğini savunmaktadırlar. Bir diğer deyişle sinizm, otorite ve örgüte karşı olumsuz ve güvensiz tavırlar içinde olmaktır (Bateman vd., 1992: 768). Andersson'a (1996: 1395) göre örgütsel sinizm; çalışanın hayal kırıklığı, umutsuzluk ve engellenme duygularını benimsemesi ile yöneticilerine ve örgütüne yönelik nefret ve güvensizlik yaşamasıdır. Wilkerson vd. (2008: 2274) göre sinizm; personelin örgütünün yönetmeliklerine, faaliyet süreçlerine ve yönetim kademesine karşı, bu unsurların çalışanın kendi çıkarlarının aleyhine olduğu inancına dayanan olumsuz bir tutum olarak tanımlanmaktadır.

Johnson ve O'Leary-Kelly’a (2003: 640-641) göre örgütsel sinizm, yalnızca olumsuz tutumda olan insanların örgütte var ettiği bir olgu olmadığını, bunun aksine sinizmin iş yaşamındaki deneyimler sonucu oluştuğunu da vurgulamaktadırlar. Hatta Andersson ve Bateman (1997: 450) sinizmin yalnız örgütsel olarak değil, bir sözleşmeye, ideolojiye, gruba ve bireye karşı da olumsuz ve güvensiz tavırlarda bulunulmasının da sinizmi meydana getirebileceğini savunmaktadırlar.

Dean vd. (1998: 345-346) örgütsel sinizmi, üç boyuttan oluşan ve olumsuz bir tutum olarak tanımlamaktadırlar. Bu tutumlardan birincisi bilişsel boyuttur; çalışanın örgütün samimiyetten, dürüstlükten ve adil olmaktan yoksun olduğuna inanmasıdır. İkincisi duyuşsal boyuttur; çalışanın örgütüne yönelik olumsuz tavırlar sergilemesi, örneğin örgüte yönelik öfke duyma, stresli olma, tiksinti ve utanç hissetmesidir. Sonuncu ise davranışsal boyuttur; bu ise çalışanın oluşan inanç ve tavırları ile birlikte örgüte karşı eleştirel ve aşağılayıcı bir tutum ve davranışa bürünmesidir.

Sinik çalışanlar, tüm örgütü etkileme ve örgütün hedeflerine ulaşmasını engelleme potansiyeline sahiptirler (Nafei ve Kaifi, 2013: 131). Sinik tutum ve davranışa sahip olan ve "sinikler" diye tabir edilen bu nitelikteki kişiler; başkalarını yalancı, güvenilmez, tembel, bencil ve samimiyetsiz olarak görmektedirler (Barefoot vd., 1989: 48). İşgörenler sinik davranışlarını ifade etmek istediklerinde, mizahı özellikle alaycı mizahı kullanmaktan memnuniyet duymaktadırlar (Dean vd., 1998: 346). Personel sözsüz olarak çalışma arkadaşları ile anlamlı bakışmaları, sırıtmaları ve küçümser biçimde gülümsemeleriyle sinik davranışlar sergilemektedirler (Perrewe ve Ganster, 2006: 240).

Sinikler, yöneticilerin kendi çıkarlarını ve ekonomik refahlarını, örgüt çalışanların çıkarlarından üstün tuttuğunu varsaymaktadırlar (Evans vd., 2011: 83). Sinik düşünceye sahip olan çalışanlar, örgüt yöneticilerinin samimiyetten uzak ve kendi imajlarını koruma amacına yönelik kararlar aldığını, üstelik örgütün gelişmesine yönelik alınan değişim kararlarının kendi çıkarlarını koruma güdüsü taşıdığına inanmaktadırlar (Koçel, 2014: 536). Diğer yandan, örgüt yönetiminin sinizmi anlama ve sinik çalışanları da ortak bir amaç birliği içine katmaya çalışması, iş hayatında hayati bir önem arz etmektedir (Kaygın ve Kosa, 2019: 366). Örneğin çalışanların fikirlerini, eleştirilerini dinlemek, varsa önceden yapmış oldukları hatalarını affetme ve örgütsel değişim süreçlerinde çalışanları da dâhil ederek onları sürekli bilgilendirmeye çalışmak, örgütte sinik davranışları yönetmek adına başarılı olacağı düşünülmektedir (Taslak ve Çiftçi, 2016: 279).

Örgütsel özdeşleşme ile örgütsel sinizm birbirleriyle tezat anlamlara sahiptir. Örgütlerin çalışanlarıyla özdeş hale gelmeleri önemli iken çalışanların sinik davranışlarını da azaltmaları veya tamamen ortadan kaldırmaları gerekmektedir. Çalışma hayatı içinde özel sektörün yanı sıra kamu 
sektöründe de her iki tür davranış şekilleri görülebilmektedir. Örgütlerdeki yöneticiler, örgütsel özdeşleşmeye yönelik uygulamalara yer verirken çalışanlarının sinik duygu, düşünce ve davranışlarına sebebiyet verecek olumsuz uygulamalardan da mümkün olduğunca kaçınmaları icap etmektedir. Örgütlerde örgütsel özdeşleşmenin artması durumunda, örgütsel sinizmin azalacağ1 düşünülmektedir. Sonuç olarak bu iki konu arasında negatif bir ilişki olduğu söylenebilir.

\subsection{Literatür Taraması}

Örgütsel özdeşleşme, kuruma yönelik olumlu sonuçlar ile karşılaşılması iken örgütsel sinizm kurumun faaliyetlerini etkileyen olumsuz tutumlar olarak değerlendirilmektedir (Ayık vd., 2016: 244). Sezgin ve Kalay (2014: 1365), örgütsel özdeşleşme düzeyinin örgütsel sinizm ile azalarak kurumun verimliliğinin düşeceğini savunmaktadırlar. Aypar vd. (2018: 117) ise kurumuyla özdeşleşme düzeyi daha yüksek olan personelin, özdeşleşme düzeyi düşük olan personele göre daha yüksek seviyede iş tatminine sahip olabileceğini ileri sürmektedirler. Polat ve Meydan (2010: 154) örgütsel özdeşleşme ile örgütsel sinizm arasında negatif bir ilişki olabileceğini iddia etmektedirler.

Bedeian (2007) Amerika Birleşik Devletleri'nde görev yapan 379 akademik personel ile yaptığ1 çalışmada, örgütsel sinizm ile örgütsel özdeşleşmenin negatif yönlü bir ilişkisinin olduğunu tespit etmiştir (Bedeian, 2007: 24). Polat ve Meydan (2010) ise Ankara'da özel bir işletmede çalışan 172 çalışandan elde ettiği veriler sonucunda, örgütsel sinizm ile örgütsel özdeşleşme düzeyleri arasında negatif ve istatiksel olarak anlamlı bir ilişki bulunduğunu tespit etmiştirler (Polat ve Meydan, 2010: 158). Yine diğer bir araştırmada, Polat vd. (2010) Ankara'da faaliyet gösteren bir kamu üniversitesinin idari bilimler ve yabancı diller bölümünden 69 akademik personel üzerinde yaptığ1 çalışma sonucunda, örgütsel özdeşleşmenin örgütsel sinizm üzerinde negatif yönlü ve istatistiksel olarak anlamlı bir ilişkisinin bulunduğunu tespit etmiştirler (Polat vd., 2010: 13).

Argon ve Ekinci (2016) 2013-2014 eğitim öğretim yılında, Bolu merkez ilçesinde bulunan ilkokul ve ortaokullarda görev yapan 636 öğretmen üzerinde yaptıkları çalışma sonucunda; örgütsel özdeşleşme ve örgütsel sinizm arasında negatif yönlü, orta düzeyde ve istatistiksel olarak anlamlı bir ilişkinin bulunduğunu ifade etmektedirler (Argon ve Ekinci, 2016: 12). Şantaş vd. (2016) Kırıkkale ilinde faaliyet gösteren bir eğitim ve araştırma hastanesinin 492 personeli üzerinde yaptıkları çalışma sonucunda; örgütsel sinizm ve örgütsel özdeşleşme arasında orta düzeyde, negatif yönlü ve istatistiksel olarak anlamlı bir ilişkinin bulunduğunu tespit etmiştirler (Şantaş vd., 2016: 879).

Yakın vd. (2017) Ankara ilinde, Türk Şeker Fabrikası A.Ş.'nin dört fabrikasında 199 kişi ile gerçekleştirdikleri çalışmada, örgütsel özdeşleşme ile örgütsel sinizm arasında negatif ve anlamlı bir ilişki bulunduğunu belirtmiştirler (Yakın vd., 2017: 75). Tuna vd. (2018) ise İstanbul'da dört farklı hastanedeki 215 hemşire üzerine yaptıkları çalışmada, örgütsel özdeşleşme ile örgütsel sinizm arasındaki ilişkiyi negatif, anlamlı ve orta düzeyde tespit etmiştirler (Tuna vd., 2018: 1712). Kerse ve Karabey (2019), Aksaray ilinde faaliyet gösteren 218 banka çalışanı üzerinde yaptıkları çalışma sonucunda, örgütsel sinizmin örgütsel özdeşleşmeyi negatif yönlü ve istatistiksel olarak anlamlı olarak etkilediğini tespit etmiştirler (Kerse ve Karabey, 2019: 97). Gerçekleştirilen literatür çalışması neticesinde örgütsel özdeşleşme ile örgütsel sinizm arasında negatif bir ilişki olduğu ifade edilebilir.

Diğer yandan, üniversitelerde görev yapan idari personele yönelik çalışmalar, az da olsa, alan yazında mevcuttur. Kalay vd. (2014) bir kamu üniversitesinde 240 akademik ve idari personel üzerinde mobbing, örgütsel sessizlik ve örgütsel sinizm ilişkisini incelemiştirler. Karcıŏlu ve Naktiyok (2015) Atatürk Üniversitesinin merkez yerleşkesinde yer alan fakülte, yüksekokul ve meslek yüksekokullarında görev yapan 301 idari personel üzerinde algılanan güven düzeyinin sinizm üzerindeki rolünü incelemiştirler. Akdemir vd. (2016) Tunceli Üniversitesi ve Kafkas Üniversitesinde akademik, idari ve yardımcı hizmetler personeli olarak görev yapan 529 kişi üzerinde örgütsel sinizm ile iş performansı ilişkisini incelemiştirler. Işık ve Zincirkıran (2016) Doğu Anadolu Bölgesi'nde 
bulunan üniversitelerde görev yapan 883 akademik ve idari personel üzerinde kurumsal itibar algısının iş tatminine etkisinde örgütsel özdeşleşmenin aracı rolünü incelemiştirler.

Taşlıyan vd. ise (2016) Kırıkkale Üniversitesinde görev yapan, toplamda 301 akademik ve idari personelin farklılık yönetiminin örgütsel özdeşleşme üzerine etkisini araştırmıştırlar. Özdemir vd. (2018) Ahi Evran Üniversitesinde görev yapan 208 idari personel üzerinde otantik liderlik ve örgütsel sinizm arasındaki ilişkide, demografik faktörlerin düzenleyici etkisini incelemiştirler. Koyuncu ve Büyükyılmaz (2020) Karabük Üniversitesinde görev yapan 350 idari personel üzerinde, psikolojik sözleşme ihlal algısının örgütsel güven ve örgütsel özdeşleşmeye etkisini belirlemeye yönelik çalışma yapmıştırlar. Battal (2020) ise Türkiye'nin doğu illerinden birinde faaliyet yürüten bir devlet üniversitesinin 206 akademik ve idari personeline örgütsel adalet ve örgütsel bağlılık ilişkisinde örgütsel özdeşleşmenin rolüne yönelik bir çalışma gerçekleştirmiştir. Yapılan literatür taraması sonucunda örgütsel özdeşleşme ve örgütsel sinizm ilişkisine yönelik idari personel üzerinde yapılan çalışmaların yeterli düzeyde olmadı̆̆ı görülmektedir.

\section{ARAŞTIRMANIN METODOLOJISİ}

$\mathrm{Bu}$ araştırmanın metodolojisini, araştırmanın amacı ve hipotezleri, araştırmanın evreni ve örneklemi, araştırmada kullanılan veri setlerine ilişkin bilgilere yer verilirken, bulgular kısmında araştırmanın analizleri ve hipotezlerine yer verilmektedir.

\subsection{Araştırmanın Amacı ve Hipotezleri}

$\mathrm{Bu}$ çalışmanın amacı, örgütsel özdeşleşme ile örgütsel sinizm arasındaki ilişkiyi tespit etmektir. Ayrıca Denizli ilindeki Pamukkale Üniversitesinin Kınıklı Yerleşkesinde bulunan Fakültelerde görev yapan idari personelin örgütsel özdeşleşme ve örgütsel sinizme ilişkin tutumlarını belirlemektir. Araştırmanın diğer bir amacı da demografik değişkenler bakımından gruplar arasında farkların olup olmadığını tespit etmektir.

Örgütsel özdeşleşme ve örgütsel sinizm konusunda kamu sektöründe, özellikle de üniversite alanında yapılan çalışmalar oldukça azdır. Kamu sektöründe çalışan ve bilhassa idari kesimde görev yapan personelin örgütsel özdeşleşme düzeylerinin tespit edilmesi önemlidir. Çünkü örgütsel özdeşleşmenin sağlandığı kurumlarda, çalışanların moral ve motivasyonlarının daha iyi olmasının yanı sıra örgütsel performans ve verimlilik düzeylerinde de önemli artışlar görülmektedir. Diğer taraftan örgütüyle özdeş hale gelen idari personelin sinik davranış ve tutumlara daha az girmesi beklenmektedir. Bu gibi nedenlerle araştırma kapsamına idari personel dâhil edilmiştir.

Araştırmanın hipotezleri aşağıda belirtilmektedir:

$\mathrm{H}_{1}$ : Örgütsel özdeşleşme ile örgütsel sinizm arasında negatif yönde bir ilişki vardır.

$\mathrm{H}_{2}$ : Örgütsel özdeşleşme cinsiyete göre farklılık göstermektedir.

$\mathrm{H}_{3}$ : Örgütsel özdeşleşme medeni duruma göre farkl1lık göstermektedir.

$\mathrm{H}_{4}$ : Örgütsel özdeşleşme yaşa göre farkl11ık göstermektedir.

$\mathrm{H}_{5}$ : Örgütsel özdeşleşme eğitim durumuna göre farkl1l1k göstermektedir.

$\mathrm{H}_{6}$ : Örgütsel özdeşleşme maaş düşünceleri bakımından farklılık göstermektedir.

$\mathrm{H}_{7}$ : Örgütsel sinizm cinsiyete göre farklılık göstermektedir.

$\mathrm{H}_{8}$ : Örgütsel sinizm medeni duruma göre farkl1lık göstermektedir.

$\mathrm{H}_{9}$ : Örgütsel sinizm yaşa göre farkl1l1k göstermektedir.

$\mathrm{H}_{10}$ : Örgütsel sinizm eğitim durumuna göre farklılık göstermektedir.

$\mathrm{H}_{11}$ : Örgütsel sinizm maaş düşünceleri bakımından farklılık göstermektedir. 


\subsection{Araştırmanın Evreni ve Örneklemi}

Pamukkale Üniversitesinin bütün birimlerinde, toplam 1423 idari personel bulunmaktadır (Sayılarla PAU, 2019). Bu miktara üniversitenin değişik yerleşkelerinde bulunan enstitüler, fakülteler, yüksekokullar, meslek yüksekokulları ve diğer birimlerde görev yapan idari personel dâhildir. Bu araştırmanın evrenini ise sadece Kınıklı Yerleşkesinde bulunan İktisadi ve İdari Bilimler Fakültesi, Eğitim Fakültesi, Fen-Edebiyat Fakültesi, Mühendislik Fakültesi, Teknoloji Fakültesi, Mimarlık ve Tasarım Fakültesi, İlahiyat Fakültesi, İletişim Fakültesi, Turizm Fakültesi, Sağlık Bilimleri Fakültesi, Müzik ve Sahne Sanatları Fakültesi, Spor Bilimleri Fakültesi ve Rektörlük biriminde görev yapan idari personel oluşturmaktadır. Aynı yerleşkede bulunan Tıp Fakültesi ve Diş Hekimliği Fakültesi araştırmaya dâhil edilmemiştir. Ayrıca Kınıklı yerleşkesindeki enstitüler, yüksekokullar ve öğrenim birimleri çalışma kapsamına alınmamıştır.

Araştırma için gerekli izinler alınmış olup verilerin toplanmasında anket yöntemi uygulanmıştır. Çalışmanın anketleri 2019 yılının Temmuz-Ağustos aylarında toplanmıştır. Araştırmada kolayda örneklem metodu tercih edilmiş olup gönüllü olarak araştırmaya katılan personele anket yöntemi uygulanmıştır. Anket sorularına cevaplayıcıların doğru cevaplar verdiği varsayılmıştır.

Araştırmanın evreni olan Kınıklı Yerleşkesindeki Fakültelerde görev yapan idari personele 300 adet anket formu dağıtılmış ve 176 kişiden geri dönüş sağlanmıştır. Elde edilen veri setlerinden iki tanesi değerlendirme dışı bırakılmış ve toplamda 174 veri seti çalışmaya uygun bulunup çalışmanın örneklemini oluşturmuştur.

\subsection{Araştırmada Kullanılan Ölçekler}

Bu çalışmanın araştırma bölümünde anket yöntemi kullanılarak verilere ulaşılmıştır. Araştırmada veri setinin birinci kısmında sekiz soruluk demografik özellikler yer almaktadır. İkinci ve üçüncü bölümünde yer alan örgütsel özdeşleşme ve örgütsel sinizm konularının araştırma ifadeleri, beşli likert tipi ölçek (1- Kesinlikle Katılmıyorum, 2- Katılmıyorum, 3- Kararsızım, 4- Katılıyorum, 5Kesinlikle Katılıyorum) kullanılarak oluşturulmuştur.

Örgütsel özdeşleşme düzeyini ölçmek için Saruhan'ın tezinde kullandığı ölçek kullanılmıştır. Ölçek 6 ifadeden oluşmaktadır. Saruhan'ın belirtiğine göre, Mael ve Ashforth'un yapmış olduğu güvenirlik analizinde Cronbach's Alpha güvenirlik katsayını 0,87 olarak bulunmuştur (Saruhan, 2017: 56). Bu çalışmada ise, yapılan güvenirlik analizinde 0,84 güvenirlik katsayısına ulaşılmıştır.

Örgütsel sinizm düzeyini ölçmek için Kalağan'ın tezinden yararlanılmıştır. Bu eserde, Brandes vd. (1999) tarafından geliştirilmiş olan “Örgütsel Sinizm Ölçeği” kullanılmıştır. Bu ölçek Brandes’in (1997) geliştirmiş olduğu 14 maddelik örgütsel sinizm ölçeğinden davranışsal boyutta yer alan bir ifade çıkartılmış ve 13 maddelik ölçek elde edilmiştir. Brandes vd. (1999) örgütsel sinizmin üç boyutta toplandığını ifade etmişlerdir. Birinci boyut bilişsel boyut adını alıp, beş maddeden (1. 2. 3 . 4. ve 5. ifadeler) oluşurken maddelerin faktör yükleri 0,63 ile 0,81 arasında hesaplamışlar ve Cronbach's Alpha güvenirlik katsayını 0,86 olarak bulmuşlardır. İkinci boyut duyuşsal boyut adını alıp, dört maddeden (6. 7. 8. ve 9. ifadeler) oluşurken maddelerin faktör yükleri 0,75 ile 0,80 arasında hesaplamışlardır. Cronbach's Alpha güvenirlik katsayını da 0,80 olarak tespit etmişlerdir. Son olarak davranışsal boyuttaki dört madde (10.11. 12. ve 13. ifadeler) 0,54 ile 0,80 arasında madde yüklerine sahip olup Cronbach's Alpha güvenirlik katsayısı ise 0,78 olarak tespit edilmiştir (Kalağan, 2009: 121). Bu çalışmada bulanan Cronbach's Alpha güvenirlik katsayısı ise 0,87 olarak bulunmuştur.

Örgütsel özdeşleşme ve örgütsel sinizm ölçeğinin çarpıklık (Skewness) ve basıklık (Kurtosis) değerleri -2 ile +2 değerleri arasında (Şencan, 2005: 200-201) olduğu görülüp dağılımın normal dağılıma uymasından dolayı parametrik testlerin yapılmasının uygun olduğuna karar verilmiştir. 


\section{4. Örgütsel Özdeşleşme Faktör Analizi Bulguları}

Ölçeğin geçerlilik analizi için faktör analizi yapılmış ve 6 madde tek faktörde toplanmıștır. KaiserMeyer-Olkin (KMO) örneklem yeterliliği 0,848, Barlett Testi 413,761, Serbestlik Derecesi (df) 15 ve anlamlılık 0,00 olarak bulunmuştur.

Tablo 1: Örgütsel Özdeşleşme Dağılımları ve Faktör Yükleri

\begin{tabular}{|c|c|c|c|c|}
\hline Örgütsel Özdeşleşme & $\mathbf{N}$ & $\overline{\mathbf{x}}$ & SS & $\begin{array}{l}\text { Faktör } \\
\text { Yükleri }\end{array}$ \\
\hline $\begin{array}{l}\text { 1. Biri çalıştı̆̆ım kurumu eleştirdiğinde/ayıpladığında bunu, } \\
\text { kendime hakaret edilmiş gibi hissederim. }\end{array}$ & 174 & 3,60 & 1,1313 &, 760 \\
\hline $\begin{array}{l}\text { 2. Diğer kişilerin çalıştı̆ıı kurum hakkındaki düşünceleri } \\
\text { çok ilgimi çeker. }\end{array}$ & 174 & 3,60 & 1,0790 &, 554 \\
\hline $\begin{array}{l}\text { 3. Çalışı̆ğım kurum hakkında konuşurken genellikle "onlar" } \\
\text { yerine "biz" ifadesini kullanırım. }\end{array}$ & 174 & 3,85 & 1,0183 & ,846 \\
\hline 4. Çalıştığım kurumun başarısı benim başarımdır. & 174 & 3,72 & 1,0390 & 851 \\
\hline $\begin{array}{l}\text { 5. Biri çalıștı̆ı̆ım kurumu övdüğünde, bunu kişisel bir } \\
\text { övgüymüș gibi hissederim. }\end{array}$ & 174 & 3,43 & 1,1696 & ,768 \\
\hline $\begin{array}{l}\text { 6. Medyada çalıştığım kurum ile ilgili olumsuz haber olursa } \\
\text { bundan rahatsızlık duyarım. }\end{array}$ & 174 & 4,04 & ,9545 & 699 \\
\hline \multicolumn{5}{|l|}{$\begin{array}{l}\text { Örgütsel Özdeşleşme Ortalaması }(\bar{x})=3,71 \\
\text { Cronbach's Alpha }(\alpha)=0,84 \\
\text { Açıklanan Toplam Varyans }=0,57\end{array}$} \\
\hline
\end{tabular}

Örgütsel özdeşleşme ölçeğinin aritmetik ortalamalarına bakıldığında en düşük oranı $(\overline{\mathrm{x}}=3,43)$ ile "Biri çalıştığım kurumu övdüğünde, bunu kişisel bir övgüymüş gibi hissederim" ifadesi almıştır. En yüksek oranı ise $(\overline{\mathrm{x}}=4,04)$ ile "Medyada çalıştığım kurum ile ilgili olumsuz haber olursa bundan rahatsızlık duyarım" ifadesi olduğu tespit edilmiştir. Ayrıca ölçekteki ifadelerin faktör yüklerinin 0,50 ’nin üstünde olduğu görülmektedir. Faktör analizi sonucunda ölçeğin geçerli olduğu tespit edilmiştir.

\section{5. Örgütsel Sinizm Faktör Analizi Bulguları}

Ölçeğin geçerlilik analizi için faktör analizi yapılmış ve 13 ifadenin üç faktörde toplandığı tespit edilmiştir. Bu faktörlere Bilişsel Boyut, Duyuşsal Boyut ve Davranışsal Boyut isimleri verilmiştir. Faktör analizi sonucunda Kaiser-Meyer-Olkin (KMO) örneklem yeterliliği 0,854, Barlett Testi 1474,417, Serbestlik Derecesi (df) ,78 ve anlamlılık 0,00 olarak bulunmuştur.

Tablo 2: Örgütsel Sinizm Dağılımları ve Faktör Yükleri

\begin{tabular}{|c|c|c|c|c|}
\hline Örgütsel Sinizm & $\mathbf{N}$ & $\overline{\mathbf{x}}$ & SS & $\begin{array}{l}\text { Faktör } \\
\text { Yükleri }\end{array}$ \\
\hline $\begin{array}{l}\text { 1. Calıştığım kurumda söylenenler ile yapılanların farklı } \\
\text { olduğuna inanıyorum. }\end{array}$ & 174 & 3,12 & 1,1101 & ,605 \\
\hline $\begin{array}{l}\text { 2. Çalıștı̆̆ı kurumun politika, amaç ve uygulamaları } \\
\text { arasında çok az ortak nokta vardır. }\end{array}$ & 174 & 2,97 & ,9761 &, 721 \\
\hline $\begin{array}{l}\text { 3. Çalıştı̆̆ım kurumda, bir uygulamanın yapılacağ } 1 \\
\text { söyleniyorsa, bunun gerçekleşip gerçekleşmeyeceği } \\
\text { konusunda şüphe duyarm. }\end{array}$ & 174 & 2,89 & 1,0428 & ,703 \\
\hline $\begin{array}{l}\text { 4. Çalıștı̆ı̆ım kurumda, çalışanlardan bir şey yapması } \\
\text { beklenir, ancak başka bir davranış ödüllendirilir. }\end{array}$ & 174 & 3,04 & 1,0878 &, 529 \\
\hline $\begin{array}{l}\text { 5. Çalıștı̆ım kurumun, yapacağını söylediği şeyler ile } \\
\text { gerçekleşenler arasında çok az benzerlik görüyorum. }\end{array}$ & 174 & 2,98 & 1,0534 & ,662 \\
\hline
\end{tabular}


Tablo 2 (Devamı): Örgütsel Sinizm Dağılımları ve Faktör Yükleri

\begin{tabular}{|c|c|c|c|c|}
\hline 6. Çalıştığım kurumu düşündükçe sinirlenirim. & 174 & 2,03 & 9670 & ,885 \\
\hline 7. Çalıştı̆ım kurumu düşündükçe hiddetlenirim. & 174 & 1,94 & ,9293 &, 902 \\
\hline 8. Çalıştığım kurumu düşündükçe gerilim yaşarım. & 174 & 2,05 & 1,0439 & ,903 \\
\hline $\begin{array}{l}\text { 9. Çalıştığım kurumu düşündükçe içimi bir endişe duygusu } \\
\text { kaplar. }\end{array}$ & 174 & 2,00 & 1,0313 & ,751 \\
\hline $\begin{array}{l}\text { 10. Çalıştığım kurum dışındaki arkadaşlarıma, işte olup } \\
\text { bitenler konusunda yakınırım. }\end{array}$ & 174 & 2,06 & 1,0783 & ,567 \\
\hline $\begin{array}{l}\text { 11. Çalıştığım kurumdan ve çalışanlardan bahsedildiğinde, } \\
\text { birlikte çalıştığım kişilerle anlamlı bir şekilde bakışırız. }\end{array}$ & 174 & 2,60 & 1,2060 &, 514 \\
\hline $\begin{array}{l}\text { 12. Başkalarıyla, çalışı̆ğım kurumdaki işlerin nasıl } \\
\text { yürütüldüğü hakkında konuşurum. }\end{array}$ & 174 & 2,50 & 1,2009 & ,691 \\
\hline $\begin{array}{l}\text { 13. Başkalarıyla, çalıştığım kurumdaki uygulamaları ve } \\
\text { politikaları eleştiririm. }\end{array}$ & 174 & 2,40 & 1,2160 & ,748 \\
\hline \multicolumn{5}{|l|}{$\begin{array}{l}\text { Örgütsel Sinizm Ortalaması }(\bar{x})=2,51 \\
\text { Cronbach's Alpha }(\alpha)=0,78 \\
\text { Açıklanan Toplam Varyans }=0,69\end{array}$} \\
\hline
\end{tabular}

Örgütsel sinizmin aritmetik ortalamaları incelendiğinde en düşük $(\overline{\mathrm{x}}=1,94)$ oranı "Çalıştığım kurumu düşündükçe hiddetlenirim" ifadesi alırken, en yüksek $(\overline{\mathrm{x}}=3,12)$ oranı "Çalıştığım kurumda söylenenler ile yapılanların farklı olduğuna inanıyorum" ifadesi tespit edilmiştir. Bu ölçekte yer alan ifadelerin faktör yükleri de 0,50 değerinin üstündedir.

Tablo 3: Örgütsel Sinizm Boyutları

\begin{tabular}{|c|c|c|c|}
\hline Örgütsel Sinizm & $\begin{array}{c}\text { 1- Bilişsel } \\
\text { Boyut }\end{array}$ & $\begin{array}{l}\text { 2- Duyuşsal } \\
\text { Boyut }\end{array}$ & $\begin{array}{l}\text { 3- Davranışsal } \\
\text { Boyut }\end{array}$ \\
\hline $\begin{array}{l}\text { 1. Calıştı̆̆ı̆m kurumda söylenenler ile yapılanların farklı } \\
\text { olduğuna inanıyorum. }\end{array}$ & ,757 & & \\
\hline $\begin{array}{l}\text { 2. Çalıştığım kurumun politika, amaç ve uygulamaları } \\
\text { arasında çok az ortak nokta vardır. }\end{array}$ & ,846 & & \\
\hline $\begin{array}{l}\text { 3. Çalıștı̆ım kurumda, bir uygulamanın yapılacağ } 1 \\
\text { söyleniyorsa, bunun gerçekleşip gerçekleşmeyeceği } \\
\text { konusunda şüphe duyarım. }\end{array}$ & ,804 & & \\
\hline $\begin{array}{l}\text { 4. Çalıștı̆ı̆ım kurumda, çalışanlardan bir şey yapması } \\
\text { beklenir, ancak başka bir davranış ödüllendirilir. }\end{array}$ & ,692 & & \\
\hline $\begin{array}{l}\text { 5. Çalıștı̆ım kurumun, yapacağını söylediği şeyler ile } \\
\text { gerçekleșenler arasında çok az benzerlik görüyorum. }\end{array}$ & ,749 & & \\
\hline 6. Çalıştığım kurumu düşündükçe sinirlenirim. & & 897 & \\
\hline 7. Çalıştı̆ım kurumu düşündükçe hiddetlenirim. & & ,895 & \\
\hline 8. Çalıştığım kurumu düşündükçe gerilim yaşarım. & & ,906 & \\
\hline $\begin{array}{l}\text { 9. Çalıştı̆ı̆ım kurumu düşündükçe içimi bir endişe duygusu } \\
\text { kaplar. }\end{array}$ & & ,804 & \\
\hline $\begin{array}{l}\text { 10. Çalıştı̆̆ım kurum dışındaki arkadaşlarıma, işte olup } \\
\text { bitenler konusunda yakınırım. }\end{array}$ & & &, 585 \\
\hline $\begin{array}{l}\text { 11. Çalıştı̆ı̆ım kurumdan ve çalışanlardan bahsedildiğinde, } \\
\text { birlikte çalıştığım kişilerle anlamlı bir şekilde bakışırız. }\end{array}$ & & &, 509 \\
\hline $\begin{array}{l}\text { 12. Başkalarıyla, çalıştığım kurumdaki işlerin nasıl } \\
\text { yürütüldügü hakkında konuşurum. }\end{array}$ & & &, 831 \\
\hline $\begin{array}{l}\text { 13. Başkalarıyla, çalışı̆ı̆ım kurumdaki uygulamaları ve } \\
\text { politikaları eleştiririm. }\end{array}$ & & & ,838 \\
\hline \multicolumn{4}{|l|}{$\begin{array}{l}\text { 1- Bilişsel Boyut, Açılanan Varyans }=0,43 \\
\text { 2- Duyuşsal Boyut, Açıklanan Varyans }=0,16 \\
\text { 3- Davranışsal Boyut, Açıklanan Varyans }=0,098 \\
\text { Açılanan Toplam Varyans }=0,69\end{array}$} \\
\hline
\end{tabular}


Yapılan faktör analizi sonucu ölçek, üç boyut altında toplanmıştır. Birinci boyut olan Bilişsel Boyutta beş faktör (1., 2., 3., 4., ve 5. ifadeler), ikinci boyut olan Duyuşsal Boyutta dört faktör (6., 7., 8., ve 9. ifadeler) ve üçüncü boyut olan Davranışsal Boyutta da dört faktör (10., 11., 12., ve 13. ifadeler) yer almıştır.

\section{BULGULAR}

Araştırmanın bu kısmında ilk önce demografik bulgular verilmiş ve daha sonra da hipotez bulguları belirtilmeye çalışılmıştır. Ayrıca, örgütsel özdeşleşme ve örgütsel sinizmin korelasyonu ve örgütsel özdeşleşme ile örgütsel sinizm boyutlarının regresyon bulguları yer almaktadır.

\subsection{Demografik Bulgular}

Bu bölümde demografik bulgular ve hipotezlere ilişkin bulgular olan örgütsel özdeşleşme ve örgütsel sinizmin cinsiyete, medeni duruma, yaşa, eğitim durumuna ve maaş düşüncesine yönelik gruplar arasındaki farklılıklar incelenmektedir.

Tablo 4: Demografik Bulgular

\begin{tabular}{|c|c|c|c|}
\hline Soru & Seçenekler & f (Sıklık) & \% (Yüzde) \\
\hline \multirow{2}{*}{ 1. Cinsiyet } & Kadın & 63 & 36,2 \\
\hline & Erkek & 111 & 63,8 \\
\hline \multirow{2}{*}{ 2. Medeni Durum } & Evli & 127 & 73,0 \\
\hline & Bekâr & 47 & 27,0 \\
\hline \multirow{3}{*}{ 3. Yaş } & $25-35$ & 55 & 31,6 \\
\hline & $36-45$ & 78 & 44,8 \\
\hline & 46 ve Üstü & 41 & 23,6 \\
\hline \multirow{4}{*}{ 4. Eğitim } & Lise & 29 & 16,7 \\
\hline & Ön Lisans & 25 & 14,4 \\
\hline & Lisans & 98 & 56,3 \\
\hline & Lisansüstü & 22 & 12,6 \\
\hline \multirow{2}{*}{ 5. Çalışma Durumu } & Kadrolu & 163 & 93,7 \\
\hline & Sözleşmeli & 11 & 6,3 \\
\hline \multirow{4}{*}{ 6. Unvanlar } & Memur & 88 & 50,6 \\
\hline & Bilgisayar İşletmeni & 50 & 28,7 \\
\hline & Şef-Müdür & 13 & 7,5 \\
\hline & Destek Hizmetleri & 23 & 13,2 \\
\hline \multirow{3}{*}{ 7. Maaş Düşüncesi } & Yeterli & 28 & 16,1 \\
\hline & Kismen Yeterli & 93 & 53,4 \\
\hline & Yetersiz & 53 & 30,5 \\
\hline \multirow{5}{*}{ 8. Hizmet Süresi } & $1-5 Y_{11}$ & 29 & 16,7 \\
\hline & $6-10 Y_{11}$ & 41 & 23,6 \\
\hline & $11-15$ Y1l & 26 & 14,9 \\
\hline & $16-20 \mathrm{Y}_{11}$ & 24 & 13,8 \\
\hline & 20 Yildan Fazla & 54 & 31,0 \\
\hline
\end{tabular}

Katılımcıların cinsiyet dağılımı \%36,2 ile kadınlardan, \%63,8'i erkeklerden oluşmaktadır. Bunlar içerisinden \%73'ü evli iken \%27'si bekâr olduklarını belirtmişlerdir. Katılımcıların \%31,6'sı 25-35 yaş aralığında, \%44,8'i 36-45 yaş aralığında ve \%23,6'sı da 46 ve üstü yaşlarda olduklarını ifade etmişlerdir. Katılımcıların eğitim düzeyleri incelendiğinde \%16,7'sinin lise mezunu, \%14,4'ünün ön lisans mezunu, \%56,3'nün lisans mezunu olduğu ve ayrıca lisans mezunlarının katılımcılar içinde en yüksek yüzdeye sahip olan kesimi oluşturmaktadır ve son olarak da \%12,6'sının lisansüstü eğitim düzeyine sahip oldukları görülmektedir. 
Çalışma durumu bakımından \%96,7'sinin kadrolu personel, \%6,3'ünün sözleşmeli personeldir. Araştırmaya katılan personelin \%50,6'sının memur olduğu, \%28,7'sinin bilgisayar işletmeni, $\% 13,2$ 'sinin destek hizmetleri ve \%7,5'inin şef-müdür unvanına sahip oldukları belirlenmiştir. Cevaplayıcıların \%16,1'i aldıkları maaşın yeterli olduğu görüşüne sahip iken \%53,4’ü kısmen yeterli olduğunu ve \%30,5'inin aldıkları maaşın yetmediğini belirtmişlerdir. Katılımcıların \%16,7'si 1-5 yı1, \%23,6's1 6-10 y1l, \%14,9'u 11-15 y11, \%13,8'i 16-20 yıl ve \%31'i 20 yıldan fazla bir süre boyunca Pamukkale Üniversitesinde idari personel olarak hizmet ettiklerini belirmişlerdir.

\subsection{Hipotez Bulguları}

Aşağıda hipotezlere ilişkin bulgular gösterilmekte ve bazı değerlendirmelerde bulunulmaktadır. $\mathrm{Bu}$ hipotezlerin bazısı kabul edilirken bazısı ise ret edilmiştir.

$\mathrm{H}_{1}$ : Örgütsel özdeşleşme ile örgütsel sinizm arasında negatif yönde bir ilişki vardır.

Tablo 5: Örgütsel Özdeşleşme ve Örgütsel Sinizmin Korelasyonu

\begin{tabular}{|c|c|c|c|c|c|c|}
\hline \multicolumn{2}{|c|}{ Ölçekler ve Boyutlar } & 1 & 2 & 3 & 4 & 5 \\
\hline \multirow{3}{*}{ 1- Örgütsel Özdeşleşme } & Pearson Korelasyonu & 1 & & & & \\
\hline & Anlamlılık (Çift Yönlü) & & & & & \\
\hline & $\mathrm{N}$ & 174 & & & & \\
\hline \multirow{3}{*}{ 2- Örgütsel Sinizm } & Pearson Korelasyonu &,$- 266^{* *}$ & 1 & & & \\
\hline & Anlamlılık (Çift Yönlü) &, 000 & & & & \\
\hline & $\mathrm{N}$ & 174 & 174 & & & \\
\hline \multirow{3}{*}{ 3- Bilişsel Boyut } & Pearson Korelasyonu &,- 125 &, $769^{* *}$ & 1 & & \\
\hline & Anlamlılık (Çift Yönlü) &, 101 &, 000 & & & \\
\hline & $\mathrm{N}$ & 174 & 174 & 174 & & \\
\hline \multirow{3}{*}{ 4- Duyuşsal Boyut } & Pearson Korelasyonu &,$- 371^{* *}$ &, $846^{* *}$ &, $482^{* *}$ & 1 & \\
\hline & Anlamlılık (Çift Yönlü) &, 000 &, 000 &, 000 & & \\
\hline & $\mathrm{N}$ & 174 & 174 & 174 & 174 & \\
\hline \multirow{3}{*}{ 5- Davranışsal Boyut } & Pearson Korelasyonu &,- 129 &, $711^{* *}$ &, $230^{* *}$ &, $501^{* *}$ & 1 \\
\hline & Anlamlılık (Çift Yönlü) & ,091 &, 000 &, 002 &, 000 & \\
\hline & $\mathrm{N}$ & 174 & 174 & 174 & 174 & 174 \\
\hline
\end{tabular}

Tablo 5'te yer alan örgütsel özdeşleşme ve örgütsel sinizmin korelasyonunda negatif yönlü, kısmen orta kuvvette ve anlamlı bir ilişki tespit edilmiştir. Bu durumda $\mathrm{H}_{1}$ hipotezi kabul edilmiştir. Bu ilişkinin $(r=-0,27) \% 30$ 'dan az olması nedeniyle ilişkinin düşük olduğu söylenebilir. Örgütsel özdeşleşme ile örgütsel sinizmin boyutlarının ilişkilerine bakıldığında; örgütsel özdeşleşme ile duyuşsal boyut arasında orta kuvvette $(r=-0,37)$ ve negatif, anlamlı bir ilişki bulunmuşken bilişsel boyut ve davranışsal boyutta anlamlı bir ilişki tespit edilememiştir.

Örgütsel özdeşleşme, işgörenlerin kurumlarına bağlılı̆̆ını ifade ederken örgütsel sinizm çalışanların kurumlarına karşı olumsuz tutum, duygu ve davranış içinde olduklarını göstermektedir. Bu kavramların birbirleriyle ters anlamda oldukları, hipotez sonucuna göre teyit edildiği söylenebilir. Diğer bir tabirle, örgütsel özdeşleşme uygulamaları artarken örgütsel sinizm azalmaktadır.

$\mathrm{H}_{2}$ : Örgütsel özdeşleşme cinsiyete göre farkl1l1k göstermektedir. 
Tablo 6: Cinsiyet Bakımından Örgütsel Özdeşleşme Farklılığ1

\begin{tabular}{|c|l|c|c|c|c|}
\hline \multirow{2}{*}{$\begin{array}{c}\text { Örgütsel } \\
\text { Özdeşleşme }\end{array}$} & Cinsiyet & $\mathbf{N}$ & $\overline{\mathbf{x}}$ & $\mathbf{S S}$ & $\boldsymbol{p}$ \\
\cline { 2 - 6 } & Kadın & 63 & 3,77 &, 7842 &, 457 \\
\cline { 2 - 6 } & Erkek & 111 & 3,67 &, 8055 &, 454 \\
\hline
\end{tabular}

Yapılan t-testi sonucunda örgütsel özdeşleşme ile cinsiyet ilişkisi arasında anlamlı bir farklılık bulunamamıştır. $\mathrm{H}_{2}$ hipotezi ret edilmiştir. Aritmetik ortalamalarına bakıldığı zaman $(\overline{\mathrm{x}}=3,77)$ kadınların erkeklere göre daha yüksek düzeyde özdeşleştiği belirtilebilir.

$\mathrm{H}_{3}$ : Örgütsel özdeşleşme medeni duruma göre farklılık göstermektedir.

Tablo 7: Medeni Durum Bakımından Örgütsel Özdeşleşme Farklılıkları

\begin{tabular}{|c|l|c|c|c|c|}
\hline \multirow{2}{*}{$\begin{array}{c}\text { Örgütsel } \\
\text { Ozdeşleşme }\end{array}$} & $\begin{array}{c}\text { Medeni } \\
\text { Durum }\end{array}$ & $\mathbf{N}$ & $\overline{\mathbf{x}}$ & $\mathbf{S S}$ & $\boldsymbol{p}$ \\
\cline { 2 - 6 } & Evli & 127 & 3,71 &, 7987 &, 973 \\
\cline { 2 - 6 } & Bekâr & 47 & 3,70 &, 8004 &, 973 \\
\hline
\end{tabular}

Yapılan t-testi sonucu ile örgütsel özdeşleşme ile medeni durum arasında anlamlı bir farklılık bulunamamıştır. $\mathrm{H}_{3}$ hipotezi ret edilmiştir. Aritmetik ortalamalarına bakıldığında evlilerin $(\overline{\mathrm{x}}=3,71)$ bekârlara göre daha yüksek düzeyde özdeşleşme yaşadığı saptanmıştır.

$\mathrm{H}_{4}$ : Örgütsel özdeşleşme yaşa göre farklılık göstermektedir.

Tablo 8: Yaşa Göre Örgütsel Özdeşleşme Farklılıkları

\begin{tabular}{|c|l|c|c|c|c|}
\hline & \multicolumn{1}{|c|}{ Yaş } & $\mathbf{N}$ & $\overline{\mathbf{x}}$ & $\mathbf{S S}$ & $\boldsymbol{p}$ \\
\hline \multirow{4}{*}{$\begin{array}{c}\text { Örgüitsel } \\
\text { Özdeşleşme }\end{array}$} & $25-35$ & 55 & 3,64 &, 8029 & \\
\cline { 2 - 5 } & $36-45$ & 78 & 3,72 &, 7119 & \multirow{2}{*}{, 708} \\
\cline { 2 - 5 } & 46 ve Üstü & 41 & 3,78 &, 9429 & \\
\cline { 2 - 5 } & Toplam & 174 & 3,71 &, 7968 & \\
\hline
\end{tabular}

Yapılan ANOVA testi sonucunda örgütsel özdeşleşme ile yaş arasında anlamlı bir farklılık bulunamamıştır. $\mathrm{H}_{4}$ hipotezi ret edilmiştir. Aritmetik ortalamalarına bakıldığında en düşük özdeşleşme $(\overline{\mathrm{x}}=3,64)$ düzeyine sahip olan 25-35 yaş aralığı iken en yüksek özdeşleşme düzeyine sahip olan $(\overline{\mathrm{x}}=3,78)$ oranı ile 46 yaş ve üzeri çalışanlar tespit edilmiştir.

$\mathrm{H}_{5}$ : Örgütsel özdeşleşme eğitim durumuna göre farklılık göstermektedir.

Tablo 9: Eğitim Durumlarına Göre Örgütsel Özdeşleşme Farklılıkları

\begin{tabular}{|c|l|c|c|c|c|}
\hline & Ĕgitim & $\mathbf{N}$ & $\overline{\mathbf{x}}$ & $\mathbf{S S}$ & $\boldsymbol{p}$ \\
\hline \multirow{4}{*}{$\begin{array}{c}\text { Örgüitsel } \\
\text { Ozzdeşleşme }\end{array}$} & Lise & 29 & 3,79 &, 9505 & \\
\cline { 2 - 5 } & Ön Lisans & 25 & 3,83 &, 6561 & \multirow{2}{*}{, 709} \\
\cline { 2 - 5 } & Lisans & 98 & 3,67 &, 7976 &, 7439 \\
\cline { 2 - 5 } & Lisansüstü & 22 & 3,62 &, 7968 & \\
\cline { 2 - 5 } & Toplam & 174 & 3,71 & \\
\hline
\end{tabular}

Yapılan ANOVA testi sonucunda örgütsel özdeşleşme ile eğitim durumu arasında anlamlı bir farklılık tespit edilememiştir. $\mathrm{H}_{5}$ hipotezi ret edilmiştir. Aritmetik ortalamalarına bakıldığında en düşük $(\overline{\mathrm{x}}=3,62)$ özdeşleşmeyi lisansüstü eğitim seviyesine sahip olanlar tespit edilirken en yüksek $(\overline{\mathrm{x}}=3,83)$ özdeşleşmeyi ise ön lisans mezunları tarafından olduğu görülmüştür.

$\mathrm{H}_{6}$ : Örgütsel özdeşleşme maaş düşünceleri bakımından farklılık göstermektedir. 
Tablo 10: Maaş Düşüncelerine Göre Örgütsel Özdeşleşme Farklılıkları

\begin{tabular}{|c|l|c|c|c|c|}
\hline & Maaş Düşüncesi & $\mathbf{N}$ & $\overline{\mathbf{x}}$ & $\mathbf{S S}$ & $\boldsymbol{p}$ \\
\hline \multirow{4}{*}{$\begin{array}{c}\text { Örgütsel } \\
\text { Ozzdeşleşme }\end{array}$} & Yeterli & 28 & 3,85 &, 6687 & \\
\cline { 2 - 5 } & K1smen Yeterli & 93 & 3,67 &, 7686 & \multirow{2}{*}{, 593} \\
\cline { 2 - 5 } & Yetersiz & 53 & 3,70 &, 9067 &, 7968 \\
\cline { 2 - 5 } & Toplam & 174 & 3,71 & \\
\hline
\end{tabular}

Yapılan ANOVA testi sonucunda örgütsel özdeşleşme ile maaş düşüncesi arasında anlamlı bir farklılık bulunamamıştır. $\mathrm{H}_{6}$ hipotezi ret edilmiştir. Aritmetik ortalamaları incelendiğinde $(\overline{\mathrm{x}}=3,67)$ en düşük düzey kısmen yeterli cevabıyken en yüksek düzeyi $(\bar{x}=3,85)$ maaşlarının yeterli olduğu görüşü tespit edilmiştir.

$\mathrm{H}_{7}$ : Örgütsel sinizm cinsiyete göre farkl1l1k göstermektedir.

Tablo 11: Cinsiyete Göre Örgütsel Sinizm Farklılıkları

\begin{tabular}{|c|l|c|c|c|c|}
\hline & \multicolumn{1}{|c|}{ Cinsiyet } & $\mathbf{N}$ & $\overline{\mathbf{x}}$ & $\mathbf{S S}$ & $\boldsymbol{p}$ \\
\hline $\begin{array}{c}\text { Bilişsel } \\
\text { Boyut }\end{array}$ & Kadın & 63 & 2,99 &, 8926 &, 927 \\
\cline { 2 - 6 } & Erkek & 111 & 3,00 &, 8078 &, 929 \\
\hline \multirow{2}{*}{$\begin{array}{c}\text { Duyuşsal } \\
\text { Boyut }\end{array}$} & Kadın & 63 & 1,98 &, 8767 &, 772 \\
\cline { 2 - 6 } & Erkek & 111 & 2,02 &, 9543 &, 767 \\
\hline \multirow{2}{*}{$\begin{array}{c}\text { Davranışsal } \\
\text { Boyut }\end{array}$} & Kadın & 63 & 2,37 &, 8216 &, 799 \\
\cline { 2 - 6 } & Erkek & 111 & 2,40 &, 8815 &, 795 \\
\hline \multirow{2}{*}{$\begin{array}{c}\text { Örgüitsel } \\
\text { Sinizm }\end{array}$} & Kadın & 63 & 2,49 &, 6581 &, 791 \\
\cline { 2 - 6 } & Erkek & 111 & 2,52 &, 6887 &, 789 \\
\hline
\end{tabular}

Yapılan t-testi sonucunda kadın ve erkekler arasında örgütsel sinizm bakımından anlamlı bir farklılık bulunamamıştır. $\mathrm{H}_{7}$ hipotezi ret edilmiştir. Aritmetik ortalamalarına bakıldığında en düşük ortalamayı kadınların $(\overline{\mathrm{x}}=1,98)$ ile erkeklerin $(\overline{\mathrm{x}}=2,02)$ ortalamaya sahip olduğu duyuşsal boyutta görülürken en yüksek ortalamanın kadınlarda $(\overline{\mathrm{x}}=2,99)$ erkeklerde $(\overline{\mathrm{x}}=3,00)$ bilişsel boyutta olduğu tespit edilmiştir.

$\mathrm{H}_{8}$ : Örgütsel sinizm medeni duruma göre farkl11ık göstermektedir.

Tablo 12: Medeni Duruma Göre Örgütsel Sinizm Farklılıkları

\begin{tabular}{|c|c|c|c|c|c|}
\hline & $\begin{array}{l}\text { Medeni } \\
\text { Durum }\end{array}$ & $\mathbf{N}$ & $\overline{\mathbf{x}}$ & SS & $p$ \\
\hline \multirow{2}{*}{$\begin{array}{l}\text { Bilişsel } \\
\text { Boyut }\end{array}$} & Evli & 127 & 3,04 & 8133 & ,308 \\
\hline & Bekâr & 47 & 2,89 & ,8981 & ,331 \\
\hline \multirow{2}{*}{$\begin{array}{c}\text { Duyuşsal } \\
\text { Boyut }\end{array}$} & Evli & 127 & 2,01 & ,9266 & ,806 \\
\hline & Bekâr & 47 & 1,97 & ,9278 & ,806 \\
\hline \multirow{2}{*}{$\begin{array}{c}\text { Davranışsal } \\
\text { Boyut }\end{array}$} & Evli & 127 & 2,36 &, 8372 & ,380 \\
\hline & Bekâr & 47 & 2,48 & 9147 & ,400 \\
\hline \multirow{2}{*}{$\begin{array}{l}\text { Örgütsel } \\
\text { Sinizm }\end{array}$} & Evli & 127 & 2,51 & ,6725 & ,806 \\
\hline & Bekâr & 47 & 2,48 & 6922, & ,809 \\
\hline
\end{tabular}


Yapılan t-testi sonucunda evli ve bekârlar içinde örgütsel sinizm bakımından anlamlı bir farklılık bulunamamıştır. $\mathrm{H}_{8}$ hipotezi ret edilmiştir. Aritmetik ortalamaları incelendiğinde en düşük ortalamaya sahip olan evlilerde $(\overline{\mathrm{x}}=2,01)$ bekârlarda $(\overline{\mathrm{x}}=1,97)$ ile duyuşsal boyut olmuştur. En yüksek ortalamaya sahip olan grup ise evlilerde $(\overline{\mathrm{x}}=3,04)$ bekârlarda $(\overline{\mathrm{x}}=2,89)$ bilişsel boyut olduğu tespit edilmiştir.

$\mathrm{H}_{9}$ : Örgütsel sinizm yaşa göre farkl11ık göstermektedir.

Tablo 13: Yaşa Göre Örgütsel Sinizm Farklılıkları

\begin{tabular}{|c|l|c|c|c|c|}
\hline & \multicolumn{1}{|c|}{ Yaş } & $\mathbf{N}$ & $\overline{\mathbf{x}}$ & $\mathbf{S S}$ & $\boldsymbol{p}$ \\
\hline \multirow{4}{*}{ Bilişsel Boyut } & $25-35$ & 55 & 2,79 &, 7953 & \multirow{3}{*}{, 023} \\
\cline { 2 - 5 } & $36-45$ & 78 & 3,18 &, 8207 & \\
\cline { 2 - 5 } & 46 ve Üstü & 41 & 2,94 &, 8651 & \\
\cline { 2 - 5 } Duyuşsal & Toplam & 174 & 3,00 &, 8369 & \\
\hline \multirow{3}{*}{ Boyut } & $25-35$ & 55 & 1,77 &, 8314 & \multirow{2}{*}{, 046} \\
\cline { 2 - 5 } & $36-45$ & 78 & 2,17 & 1,035 & \\
\cline { 2 - 5 } & 46 ve Üstü & 41 & 1,98 &, 7561 & \\
\cline { 2 - 5 } & Toplam & 174 & 2,00 &, 9247 & \\
\hline
\end{tabular}

Yapılan ANOVA testi sonucunda örgütsel sinizm ile yaş değişkenleri arasında bilişsel boyut $(p=, 023)$ ve duyuşsal boyutta $(p=, 046)$ anlamlı farklılıklar tespit edilmiştir. $\mathrm{H}_{9}$ hipotezi kabul edilmiştir. Yapılan Post Hoc-LSD Çoklu Karşılaştırma analizine göre gruplar arasındaki bu farklılık, 25-35 yaş grubu ile 36-45 yaş grubundan kaynaklandığı tespit edilmiştir.

$\mathrm{H}_{10}$ : Örgütsel sinizm eğitim durumuna göre farkl1lık göstermektedir.

Tablo 14: Eğitim Durumlarına Göre Örgütsel Sinizm Farklılıkları

\begin{tabular}{|c|c|c|c|c|c|}
\hline & Eğitim & $\mathbf{N}$ & $\overline{\mathbf{x}}$ & SS & $p$ \\
\hline \multirow{5}{*}{ Bilişsel Boyut } & Lise & 29 & 2,72 & ,7278 & \multirow{5}{*}{, 025} \\
\hline & Ön Lisans & 25 & 3,13 & ,9358 & \\
\hline & Lisans & 98 & 3,12 & ,8063 & \\
\hline & Lisansüstü & 22 & 2,68 &, 8677 & \\
\hline & Toplam & 174 & 3,00 &, 8369 & \\
\hline \multirow{5}{*}{$\begin{array}{c}\text { Duyuşsal } \\
\text { Boyut }\end{array}$} & Lise & 29 & 1,83 &, 8641 & \multirow{5}{*}{, 147} \\
\hline & Ön Lisans & 25 & 2,10 & 1,0103 & \\
\hline & Lisans & 98 & 2,10 & ,9443 & \\
\hline & Lisansüstü & 22 & 1,67 &, 7375 & \\
\hline & Toplam & 174 & 2,00 & ,9247 & \\
\hline \multirow{5}{*}{$\begin{array}{c}\text { Davranışsal } \\
\text { Boyut }\end{array}$} & Lise & 29 & 2,35 &, 8060 & \multirow{5}{*}{, 417} \\
\hline & Ön Lisans & 25 & 2,53 & ,9222 & \\
\hline & Lisans & 98 & 2,43 &, 8695 & \\
\hline & Lisansüstü & 22 & 2,13 &, 7970 & \\
\hline & Toplam & 174 & 2,39 &, 8581 & \\
\hline \multirow{5}{*}{$\begin{array}{l}\text { Örgütsel } \\
\text { Sinizm }\end{array}$} & Lise & 29 & 2,33 &, 5834 & \multirow{5}{*}{, 028} \\
\hline & Ön Lisans & 25 & 2,63 &, 7297 & \\
\hline & Lisans & 98 & 2,59 &, 6722 & \\
\hline & Lisansüstü & 22 & 2,20 & ,6481 & \\
\hline & Toplam & 174 & 2,51 &, 6760 & \\
\hline
\end{tabular}

Yapılan ANOVA testi ile cevaplayıcılar arasında eğitim durumları açısından örgütsel sinizm bakımından anlamlı farklılıklar bulunmuştur. $\mathrm{Bu}$ anlamlı farklılık bilişsel boyut $(p=0,025)$ ile örgütsel sinizm ortalamasında $(p=0,028)$ tespit edilmiştir. $\mathrm{H}_{10}$ hipotezi kabul edilmiştir. Gruplar arasındaki farklılığın hangi gruplardan kaynaklandığını bulmak amacıyla Post Hoc-LSD Analizi yapılmıştır. Bu analiz sonucuna göre bilişsel boyut açısından farklılık, lise ve lisans gruplarından 
kaynaklanmaktadır. Örgütsel sinizm açısından ise farklılık, ön lisans grubu ile lisansüstü grubundan kaynaklanmaktadır.

$\mathrm{H}_{11}$ : Örgütsel sinizm maaş düşünceleri bakımından farklılık göstermektedir.

Tablo 15: Maaş Düşüncelerine Göre Örgütsel Sinizm Farklılıkları

\begin{tabular}{|c|c|c|c|c|c|}
\hline & Maaș Düșüncesi & $\mathbf{N}$ & $\overline{\mathbf{x}}$ & SS & $p$ \\
\hline \multirow{4}{*}{ Bilişsel Boyut } & Yeterli & 28 & 2,82 & ,9162 & \multirow{4}{*}{,001 } \\
\hline & Kismen Yeterli & 93 & 2,85 &, 7459 & \\
\hline & Yetersiz & 53 & 3,36 &, 8452 & \\
\hline & Toplam & 174 & 3,00 &, 8369 & \\
\hline \multirow{4}{*}{$\begin{array}{c}\text { Duyuşsal } \\
\text { Boyut }\end{array}$} & Yeterli & 28 & 1,91 &, 8311 & \multirow{4}{*}{, 129} \\
\hline & Kismen Yeterli & 93 & 1,91 & ,9299 & \\
\hline & Yetersiz & 53 & 2,22 & ,9426 & \\
\hline & Toplam & 174 & 2,00 & ,9247 & \\
\hline \multirow{4}{*}{$\begin{array}{c}\text { Davranışsal } \\
\text { Boyut }\end{array}$} & Yeterli & 28 & 2,31 &, 8835 & \multirow{4}{*}{,602 } \\
\hline & Kismen Yeterli & 93 & 2,36 &, 8766 & \\
\hline & Yetersiz & 53 & 2,49 &, 8188 & \\
\hline & Toplam & 174 & 2,39 &, 8581 & \\
\hline \multirow{4}{*}{$\begin{array}{c}\text { Örgütsel } \\
\text { Sinizm }\end{array}$} & Yeterli & 28 & 2,38 &, 7536 & \multirow{4}{*}{,009 } \\
\hline & Kismen Yeterli & 93 & 2,41 & ,6579 & \\
\hline & Yetersiz & 53 & 2,74 &, 6147 & \\
\hline & Toplam & 174 & 2,51 &, 6760 & \\
\hline
\end{tabular}

Yapılan ANOVA testi sonucunda örgütse sinizm ile maaş düşüncesi arasında anlamlı bir farklılık tespit edilmiştir. Bu anlamlı farklılı̆̆ ortalamasında $(p=, 009)$ bulunmuştur. $\mathrm{H}_{11}$ hipotezi kabul edilmiştir.

Örgütsel sinizmin boyutlarının örgütsel özdeşleşmeyi nasıl etkilediği ile ilgili yapılan Regresyon analizi bulguları aşağıdaki tabloda gösterilmektedir.

Tablo 16: Örgütsel Özdeşleşme ile Örgütsel Sinizmin Boyutları Regresyon Bulguları

\begin{tabular}{|c|c|c|c|c|c|c|}
\hline & & Unstandardized B & $\begin{array}{c}\text { Coefficients Std. } \\
\text { Error }\end{array}$ & $\begin{array}{c}\text { Standardized } \\
\text { Coefficients } \\
\text { Beta } \\
\end{array}$ & $\mathbf{t}$ & $p$ \\
\hline \multirow[t]{4}{*}{1} & (Sabit) & 4,104 & ,241 & & 17,043 &, 000 \\
\hline & Bilişsel Boyut &, 068 & ,077 &, 071 & ,879 & ,381 \\
\hline & Duyuşsal Boyut &,- 383 &, 078 &,- 444 & $-4,880$ &, 000 \\
\hline & Davranışsal Boyut &, 072 &, 076 & ,078 & ,948 &, 345 \\
\hline
\end{tabular}

Yapılan regresyon analizi sonucunda, örgütsel sinizm boyutları arasında sadece duyuşsal boyutun örgütsel özdeşleşmeyi -0,44 oranında etkilediği görülmektedir. Diğer boyutlar bakımından anlamlı sonuçlar tespit edilememiştir. Başka bir tabirle, örgütsel özdeşleşmeyi, duyuşsal boyut \%44 oranında açıklamaktadır. Ancak bu bulgu, negatif yönlüdür. Diğer bir anlatımla, örgütsel özdeşleşme artarken duyuşsal boyut \%44 oranında azalmaktadır.

Araştırmada belirlenen hipotezlerin kabul ve ret durumları aşağıdaki tabloda özetlenmektedir. 
Tablo 17: Hipotezlerin Kabul ve Ret Durumları

\begin{tabular}{|c|c|}
\hline HİPOTEZLER & KABUL / RET DURUMLARI \\
\hline $\mathrm{H}_{1}$ : Örgütsel özdeşleme ile örgütsel sinizm arasında negatif yönde bir ilişki vardır. & KABUL \\
\hline $\mathrm{H}_{2}$ : Örgütsel özdeşleşme cinsiyete göre farklılık göstermektedir. & RET \\
\hline $\mathrm{H}_{3}$ : Örgütsel özdeşleșme medeni duruma göre farkl1lık göstermektedir. & RET \\
\hline $\mathrm{H}_{4}$ : Örgütsel özdeşleşme yaşa göre farklılık göstermektedir. & RET \\
\hline $\mathrm{H}_{5}$ : Örgütsel özdeșleşme eğitim durumuna göre farkl1lık göstermektedir. & RET \\
\hline $\mathrm{H}_{6}$ : Örgütsel özdeşleşme maaş düşünceleri bakımından farklılık göstermektedir. & RET \\
\hline $\mathrm{H}_{7}$ : Örgütsel sinizm cinsiyete göre farkl11ık göstermektedir. & RET \\
\hline $\mathrm{H}_{8}$ : Örgütsel sinizm medeni duruma göre farkl11lk göstermektedir. & RET \\
\hline $\mathrm{H}_{9}$ : Örgütsel sinizm yaşa göre farkl1lık göstermektedir. & KABUL \\
\hline $\mathrm{H}_{10}$ : Örgütsel sinizm eğitim durumuna göre farkl1lık göste & KABUL \\
\hline $\mathrm{H}_{11}$ : Örgütsel sinizm maaş düşünceleri bakımından farklılık gösterm & KABUL \\
\hline
\end{tabular}

\section{SONUÇ ve ÖNERILER}

Örgütsel yaşamda çalışanın kurumunu benimseyerek kendisi ile bir birliktelik oluşturmasıyla özdeşleşme gerçekleşirken, çalışanın kurumunu benimsemeyerek ona karşı şüpheyle yaklaşıp eleştirilerde bulunması sonucunda sinizm oluşmaktadır. Bu çalışmada, Denizli ili Pamukkale Üniversitesi Kınıklı Yerleşkesindeki Fakültelerinde görev yapan idari personelin örgütsel özdeşleşme ve örgütsel sinizm düzeyleri belirlenmeye çalışılmıştır.

Araştırma sonucuna göre örgütsel özdeşleşme ile örgütsel sinizm arasında negatif ve anlamlı ilişki söz konusudur. Bu ilişki kısmen orta kuvvette olan bir ilişkidir. Bu durumda, örgütsel özdeşleşme artarken örgütsel sinizmin azalacağı belirtilebilir.

Çalışmada, idari personelin örgütsel özdeşleşme bakımından cinsiyete göre bir farklılık gösterip göstermediği sorgulandığında anlamlı bir farklılık tespit edilememiştir. Atmaca'nın (2021: 375) çalışmasına göre de örgütsel özdeşleşme ile cinsiyet arasında anlamlı bir farklılığın olmadığ 1 görülmektedir. Aritmetik ortalamalarına bakıldığında kadınların erkeklere göre daha yüksek düzeyde özdeşleştiği belirlenmiştir. Örgütsel sinizmin cinsiyet bakımından anlamlı bir farklılık göstermesine yönelik sorgulamada anlamlı bir farklılık bulunamamıştır. Çevik ve Can (2020: 20) da yapmış oldukları çalışmada örgütsel sinizm ile cinsiyet arasında anlamlı bir farklılık bulamamıştırlar. Örgütsel sinizmin aritmetik ortalamaları sonucunda, bilişsel boyutta erkeklerin daha yüksek düzeyde sinizme sahip oldukları saptanmıştır.

İdari personelin medeni durum bakımından örgütsel özdeşleşme ile anlamlı bir farklılık tespit edilememiştir. Karataş ve Taş (2017: 101-102) tarafından yapılan çalışmada da örgütsel özdeşleşme ile medeni durum arasında anlamlı bir farklılık bulunamamıştır. Aritmetik ortalamaları incelendiğinde, evlilerin daha yüksek düzeyde özdeşleştiği belirlenmiştir. Örgütsel sinizm ile medeni durum bakımından anlamlı bir farklılık bulunamamıştır. Erer ve Şahin (2020: 2951) de yaptıkları çalışmada, örgütsel sinizm ile medeni durum arasında anlamlı bir ilişki tespit edememiştirler. Örgütsel sinizmin medeni durum bakımından aritmetik ortalamaları incelendiğinde, bilişsel boyutta evlilerin daha yüksek düzeyde sinizme sahip olduğu tespit edilmiştir.

Katılımcıların yaş bakımından örgütsel özdeşleşme ile anlamlı bir farklılık tespit edilememiştir. Akbaba'nın (2018: 326) yapmış olduğu çalışmada da örgütsel özdeşleşme ile yaş arasında anlamlı bir farklılık bulunamamıştır. Aritmetik ortalamaları neticesinde 46 yaş ve üzeri katılımcıların daha yüksek düzeyde özdeşleştiği görülmektedir. Örgütsel sinizm ile yaş arasında anlamlı bir farklılık tespit edilmiştir. Bu farklılığ hangi yaş grubunun oluşturduğunu öğrenmek için yapılan Post HocLSD Çoklu Karşılaştırma analizine göre gruplar arasındaki bu farklılık 25-35 yaş grubu ile 36-45 yaş grubundan kaynaklandığı tespit edilmiştir. Duman vd. (2020: 1110) yaptıkları çalışmada da örgütsel sinizm ile yaş arasında anlamlı bir ilişki tespit etmiştirler. 
Katılımcıların örgütsel özdeşleşme ile eğitim durumu ilişkisi değerlendirildiğinde anlamlı bir farklılık bulunamazken aritmetik ortalamaları incelendiğinde ön lisans mezunlarının yüksek düzeyde özdeşleştiği saptanmıştır. Özgözgü vd. (2017: 1071) yapmış oldukları çalışmada örgütsel özdeşleşme ile eğitim durumları arasında anlamlı bir farklılık tespit edememiştirler. Örgütsel sinizm ile eğitim durumu arasında ise anlamlı bir farklılık tespit edilmiştir. Tağraf ve Bozkulak'ın (2020: 281) da yaptıkları çalışmada örgütsel sinizm ile eğitim durumu arasında anlamlı bir farklılık bulunmuştur. $\mathrm{Bu}$ farklılığın hangi gruplardan kaynaklandığını tespit etmek amacıyla Post Hoc-LSD analizi sonucunda, bilişsel boyut bakımından farklılığ lise ve lisans mezunları oluşturduğu görülürken, örgütsel sinizm ortalamasında ön lisans ve lisansüstü mezunlarında farklılığın oluştuğu görülmektedir.

İdari personelin örgütsel özdeşleşme ile maaş düşüncesi arasında anlamlı bir farklılık tespit edilememişken aritmetik ortalamalarına göre maaşlarının yeterli olduğu görüşünde oldukları tespit edilmiştir. Korkmaz vd. (2017: 75-76) çalışmasına göre örgütsel özdeşleşme ile maaş düşüncesi arasında anlamlı bir farklılık bulunamamıştır. Örgütsel sinizm ile maaş düşüncesi arasında anlamlı bir farklılık tespit edilmiştir. Katılımcıların maaş düşünceleri yeterli, kısmen yeterli ve yeterli değil şeklinde oluşan seçeneklerden ibarettir. Küçük ve Yavuz (2021: 467) da yaptıkları çalışmada örgütsel sinizm ile maaş düşüncesi arasında anlamlı bir farklılık tespit etmişlerdir.

Örgütsel özdeşleşmeyi örgütsel sinizmin nasıl etkilediği ile ilgili yapılan regresyon analizi sonucuna göre sadece duyuşsal boyut - $\% 44$ oranında örgütsel özdeşleşmeyi açıklamaktadır. Yani duyuşsal boyut örgütsel özdeşleşmeyi -\%44 oranında etkilemektedir. $\mathrm{Bu}$ durumda örgütsel özdeşleşme uygulamalarına önem veren yöneticiler, yaklaşık \%44 oranında duyuşsal boyuttaki sinizmin menfi tesirlerini ortadan kaldırabileceklerdir.

$\mathrm{Bu}$ araştırma ile kurumlara, yöneticilere, çalışanlara ve diğer araştırmacılara yol gösterecek sonuçlar elde edilmiştir. Kamu sektöründe çalışanların kuruma özdeş olmalarını temin edecek uygulamalara yer verilmelidir. Çalışanların kuruma karşı menfi duygular beslediği örgütsel sinizmin duygu, düşünce ve davranışlara yöneltecek faaliyetlerden ve icraatlardan kaçınmak gerekmektedir.

Kurum yönetimi çalışanlar arası kayırmacılık yapmayıp, adaletli davrandığında özdeşleşme düzeyinin artarak sinik tutumların azalacağı tahmin edilmektedir. Çalışanların başarı gösterdiklerinde övülmeleri, onların kurumda değer gördüğü intibaını oluşturacaktır. Personelin fikirlerine ve müspet eleştirilerine anlayış gösterilerek kararların istişareler sonucunda alınması, çalışanların sinik davranışlara yönelmesini azaltacaktır.

Üniversite idari personeline yönelik örgütsel özdeşleşme ve örgütsel sinizmin incelenmesi üzerine fazla araştırma yapılmadığı görülmektedir. Bu nedenle çalışmanın literatüre katkı sağlayacağ1 düşünülmektedir. Bu çalışmanın bir kamu üniversitesinin bir yerleşkesinde, fakültelerde görev yapan idari personeline yönelik olması, araştırmanın sınırlılığını oluşturmaktadır. Araştırmaya enstitüler, yüksekokullar, meslek yüksekokulları ve öğrenim birimlerinde görev yapan idari personelin de dâhil edilmesi, bu konuda çalışma yapacak olan araştırmacılara tavsiye edilebilir. Ayrıca bu konularda idari personelin yanı sıra üniversitenin akademik personeline yönelik de araştırma yapılması önerilebilir.

Not: Yazarların katkı düzeyleri eşittir. Araştırma 2019 yılında yapıldığı için Etik Kurul iznine gerek görülmemiştir. 


\section{KAYNAKÇA}

Abraham, R. (2000). Organizational Cynicism: Bases and Consequences. Genetic, Social and General Psychology Monographs, 126(3), 269-292.

Akbaba, M. (2018). Otel İşletmelerinde Psikolojik Sözleşmenin İşe Yabancılaşma ve Örgütsel Özdeşleşme Üzerine Etkisi. Journal of Institute of Economic Development and Social Researches, 4(9), 320-330.

Akdemir, B., Kırmızıgül B. \& Zengin, Y. (2016). Örgütsel Sinizm ile İş Performansı Arasındaki İlişki ve Bir Araştırma. KSÜ IIBF Dergisi, 6(2), 115-130.

Andersson, L. M. \& Bateman, T. S. (1997). Cynicism in the Workplace: Some Causes and Effects. Journal of Organizational Behavior, 18(5), 449-469.

Andersson, L. M. (1996). Employee Cynicism: An Examination Using a Contract Violation Framework. Human Relations, 49(11), 1395-1418.

Argon, T. \& Ekinci S. (2016). İlk ve Ortaokul Öğretmenlerinin Örgütsel Özdeşleşme ve Örgütsel Sinizm Düzeylerine İlişkin Görüşleri. Abant İzzet Baysal Üniversitesi Ĕgitim Fakültesi Dergisi, 16(1), 1-19.

Arslan, A. (2006). İlkçağ Felsefe Tarihi 2: Sofistlerden Platon'a. İstanbul. İstanbul Bilgi Üniversitesi Yayınlar1.

Ashforth, B. E. \& Mael, F. (1989) Social Identity Theory and the Organization. The Academy of Management Review, 14(1), 20-39.

Ashforth, B. E., Harrison, S. H. \& Corley, K. G. (2008). Identification in Organizations: An Examination of Four Fundamental Questions. Journal of Management, 34(3), 325-374.

Atmaca, T. (2021). Öğretmenlerin Örgütsel Sessizlik Davranışları ve Örgütsel Özdeşleşmeleri Arasındaki İlişki. Anadolu Journal of Educational Sciences International, 11(1), 367-389.

Ayık, A., Şayir, G. \& Bilici, A. (2016). Öğretmenlerin Algılarına Göre Örgütsel Sinizmin Örgütsel Özdeşleşme Üzerindeki Yordayıcı Etkisinin İncelenmesi. Pegem Ĕgitim ve Öğretim Dergisi, 6(2), 233-254.

Aypar, S., Sökmen, A. \& Ekmekçioğlu, E. B. (2018). İş Tatmini ve İşten Ayrılma Niyeti İlişkisi: Örgütsel Özdeşleşmenin Aracılık Rolü. Gazi Üniversitesi Sosyal Bilimler Dergisi, 5(13), 116124.

Barefoot, J. C., Dodge, K. A., Peterson, B. L., Dahlstrom, W. G. \& Williams R. B. (1989). The CookMedley Hostility Scale: Item Content and Ability to Predict Survival. Psychosomatic Medicine, 51(1), 46-57.

Bateman, T. S., Sakano, T. \& Fujita, M. (1992). Roger, Me, and Attitude: Film Propaganda and Cynicism Toward Corporate Leadership. Journal of Applied Psychology, 77(5), 768-771.

Battal, F. (2020). Örgütsel Adalet ve Örgütsel Bağlılık İlişkisinde Örgütsel Özdeşleşmenin Rolü: Üniversite Çalışanları Üzerine Bir Örnek. OPUS-Uluslararası Toplum Araştırmaları Dergisi, 15(24), 2362-2393.

Bedeian, A. G. (2007). Even If the Tower Is "Ivory," It Isn't "White:" Understanding the Consequences of Faculty Cynicism. Academy of Management Learning \& Education, 6(1), 932.

Bhattacharya, C. B. \& Elsbach, K. D. (2002). Us Versus Them: The Roles of Organizational Identification and Disidentification in Social Marketing Initiatives. Journal of Public Policy \& Marketing, 21(1), 26-36.

Billig, M. \& Tajfel, H. (1973). Social Categorization and Similarity in Intergroup Behaviour. European Journal of Social Psychology, 3(1), 27-52.

Brandes, P. M. (1997). Organizational Cynicism: Its Nature, Antecedents, and Consequences (Unpublished Doctoral Dissertation). The University of Cincinnati.

Brandes, P., Castro, S. L. James, M. S. L., Martinez, A. D., Matherly, T. A., Ferris, G. R. \& Hochwarter, W. A. (2008). The Interactive Effects of Job Insecurity and Organizational 
Cynicism on Work Effort Following a Layoff. Journal of Leadership \& Organizational Studies, 14(3), 233-247.

Brandes, P., Dharwadkar, R., \& Dean, Jr. J. W. (1999). Does Organizational Cynicism Matter? Employee and Supervisior Perspectives on Work Outcomes. The 36th Annual Meeting of the Eastern Academy of Management, Philadelphia, 1-33.

Cheney, G. \& Thompkins, P. K. (1987). Coming to Terms with Organizational Identification and Commitment. Central States Speech Journal, 38(1), 1-15.

Cheney, G. (1983). On the Various and Changing Meanings of Organizational Membership: A Field Study of Organizational Identification. Communication Monographs, 50(4), 342-362.

Çevik, A. \& Can, N. (2020). Öğretmenlerin Örgütsel Vatandaşlık ve Örgütsel Sinizm Davranışlarının Yordayıcısı Olarak Okul Yöneticilerinin Makamsal Güç Kaynakları. Academia Ĕ̆gitim Araştırmaları Dergisi, 5(1), 13-30.

Dean, Jr. J. W., Brandes, P. \& Dharwadkar, R. (1998). Organizational Cynicism. Academy of Management Review, 23(2), 341-352.

Demirtaş, H. A. (2003). Sosyal Kimlik Kuramı, Temel Kavram ve Varsayımları. Iletişim: Araştırmaları Dergisi, 1(1), 123-144.

Duman, N., Sak, R., Şahin, Sak, İ. T. (2020). Öğretmenlerin Mesleki Tükenmişlik Düzeyleri ile Örgütsel Sinizm Tutumlarının İncelenmesi. YYÜ Eğitim Fakültesi Dergisi, 17(1), 1098-1127.

Dutton, J. E., Dukerich, J. M. \& Harquail, C. V. (1994). Organizational Images and Member Identification. Administrative Science Quarterly, 39(2), 239-263.

Edwards, M. R. (2005). Organizational Identification: A Conceptual and Operational Review. International Journal of Management Reviews, 7(4), 207-230.

Erer, B. \& Şahin, M. (2020). Çalışanların Örgütsel Sinizm Düzeylerinin İncelenmesi: Konya İli Örneği. İşletme Araştırmaları Dergisi, 12(3), 2944-2959.

Evans, W. R., Goodman, J. M. \& Davis, W. D. (2011). The Impact of Perceived Corporate Citizenship on Organizational Cynicism, OCB, and Employee Deviance. Human Performance, 24(1), 7997.

Gökberk, M. (1993). Felsefe Tarihi. İstanbul. Remzi Kitabevi.

Gündüz, Ş. (2017). İş Yerinde Yaşanan Sendromlar. İstanbul. Beta Basım Yayım.

Işık, M. \& Zincirkıran, M. (2016). Kurumsal İtibar Algısının İş Tatminine Etkisinde Örgütsel Özdeşleşmenin Aracı Rolü: Doğu Anadolu Bölgesindeki Üniversiteler Üzerinde Bir Uygulama. Issletme Araştırmaları Dergisi, 8(3), 89-106.

Johnson, J. L. \& O'Leary-Kelly, A. M. (2003). The Effects of Psychological Contract Breach and Organizational Cynicism: Not All Social Exchange Violations Are Created Equal. Journal of Organizational Behavior, 24(5), 627-647.

Kağıtçıbaşı, Ç. \& Cemalcılar, Z. (2019). Dünden Bugüne İnsan ve İnsanlar Sosyal Psikolojiye Giriş. İstanbul. Evrim Yayınevi.

Kalağan, G. (2009). Araştırma Görevlilerinin Örgütsel Destek Algıları ile Örgütsel Sinizm Tutumları Arasındaki İlişki. (Yayımlanmamış Yüksek Lisans Tezi). Akdeniz Üniversitesi Sosyal Bilimler Enstitüsü. Antalya.

Kalay, F., Oğrak A., Bal, Vedat. \& Nişancı Z. N. (2014). Mobbing, Örgütsel Sessizlik ve Örgütsel Sinizm İlişkisi: Örnek Bir Uygulama. Sakarya İktisat Dergisi, 3(2), 1-18.

Karataş, S. \& Taş, A. (2017). İlk ve Ortaokullardaki Öğretmenlerin Narsistik Kişilik Eğilimleri ile Örgütsel Özdeşleşme Düzeyi Arasındaki İlişkinin İncelenmesi. Uşak Üniversitesi Ĕ̆itim Araştırmaları Dergisi, 3(1), 92-121.

Karcıoğlu, M. S. \& Naktiyok, A. (2015). Örgütsel Ortamda Algılanan Güven Düzeyinin Sinizm Üzerindeki Rolü: Atatürk Üniversitesi İdari Personeli Üzerinde Bir Araştırma. $A K \ddot{U}$ IIIBF Dergisi, 17(1), 19-34.

Kaygın, E. \& Kosa, G. (Ed.). (2019). Olumsuz Boyutlarıyla Örgütsel Davranış. Konya. Eğitim Yayınevi. 
Kerse, G. \& Karabey, C. N. (2019). Örgütsel Sinizm ve Özdeşleşme Bağlamında Algılanan Örgütsel Desteğin İşe Bağlanma ve Politik Davranış Algısına Ektisi. Eskişehir Osmangazi Üniversitesi IIIBF Dergisi, 14(1), 83-108.

Koçel, T. (2014). İşletme Yöneticiliği. İstanbul. Beta Basım Yayım.

Korkmaz, O., Aydemir S. \& Uysal H. T. (2017). Örgütsel Özdeşleşme Üzerinde Örgüte Hâkim Kurum Kültürünün Etkisi. Balkan Sosyal Bilimler Dergisi, 6(12), 62-80.

Koyuncu, H. \& Büyükyılmaz O. (2020). Psikolojik Sözleşme İhlal Algısının Örgütsel Güven ve Örgütsel Özdeşleşmeye Etkisini Belirlemeye Yönelik Üniversite Çalışanları Üzerinde Bir Araştırma. Anemon Muş Alparslan Üniversitesi Sosyal Bilimler Dergisi, 8(4), 1191-1199.

Kreiner, G. H. \& Ashforth, B. E. (2004). Evidence Toward an Expanded Model of Organizational Identification. Journal of Organizational Behavior, 25(1), 1-27.

Küçük, B., \& Yavuz, E. (2021). Hizmetkâr Liderlik ve Örgütsel Sinizm Arasındaki İlişkinin İncelenmesi: Hizmet Sektöründe Bir Araştırma. Alanya Akademik Bakış Dergisi, 5(1), 453-472.

Levinson, H. (1965). Reciprocation: The Relationship between Man and Organization. Administrative Science Quarterly, 9(4), 370-390.

Mael, F. \& Ashforth, B. E. (1992). Alumni and Their Alma Mater: A Partial Test Of The Reformulated Model Of Organizational Identification. Journal of Organizational Behavior, 13(2), 103-123.

Mael, F. A. \& Ashforth, B. E. (1995). Loyal From Day One: Biodata, Organizational Identification, and Turnever Among Newcomers. Personnel Psychology, 48(2), 309-333.

Nafei, W. A. \& Kaifi, B. A. (2013). The Impact of Organizational Cynicism on Organizational Commitment: An Applied Study on Teaching Hospitals in Egypt. Europen Journal of Business and Management, 5(12), 131-147.

Özdemir, H. Ö., Erkutlu, H. V. \& Elden, B. (2018). Otantik Liderlik ve Örgütsel Sinizm Arasındaki İlişkide Demografik Faktörlerin Düzenleyici Etkisi. Uluslararası Sosyal Bilimler Dergisi, 1(2), 202-210.

Özgözgü, S., Bektaş, M., Arıkan, F. \& Şimşek, H. (2017). Okul Psikolojik Danışmanlarının Genel Öz-Yeterlik İnançları ve Örgütsel Özdeşleşme Algıları. Elementary Education Online, 16(3), $1058-1078$.

Peng, Z. \& Zhou, F. (2009). The Moderating Effect of Supervisory Conscientiousness on the Relationship Between Employees' Social Cynicism and Perceived Interpersonal Justice. Social Behavior and Personality, 37(6), 863-864.

Perrewe, P. L. \& Ganster, D. C. (Ed.). (2006). Employee Health, Coping and Methodologies. New York. JAI Press.

Polat, M. \& Meydan, C. H. (2010). Örgütsel Özdeşleşmenin Sinizm ve İşten Ayrılma Niyeti ile İlişkisi Üzerine Bir Araştırma. Savunma Bilimleri Dergisi, 9(1), 145-172.

Polat, M., Meydan, C. H. \& Tokmak İ. (2010). Personel Güçlendirme, Örgütsel Özdeşleşme ve Örgütsel Sinizm İlişkisi Üzerine Bir Araştırma. Kara Harp Okulu Bilim Dergisi, 20(2), 1-22.

Pratt, M. G. \& Rafaeli, A. (1997). Organizational Dress As A Symbol of Multilayered Social Identities. Academy of Management Journal, 40(4), 862-898.

Ravishankar, M. N. \& Pan, S. L. (2008). The Influence of Organizational Identification on Organizational Knowledge Management (KM). Omega: The International Journal of Management Science, Cilt: 36(2), 221-234.

Rotondi, T. Jr. (1975). Organizational Identification and Group Involvement. The Academy of Management Journal, 18(4), 892-897.

Rousseau, D. M. (1998). Why Workers Still Identify with Organizations. Journal of Organizational Behavior, 19(3), 217-233.

Sammarra, A. \& Biggiero L. (2001). Identity and Identification in Industrial Districts. Journal of Management and Governance, 5(1), 61-82. 
Saruhan, S. (2017). Örgütsel Sosyalleşmenin Örgütsel Özdeşleşme Üzerindeki Etkisi. (Yayımlanmamış Yüksek Lisans Tezi). Kırıkkale Üniversitesi Sosyal Bilimler Enstitüsü. Kirıkkale.

Sayılarla PAU (2019). Sayılarla Pamukkale Üniversitesi, https://www.pau.edu.tr/pau/tr/sayilarlaPAU (ET: 25.06.2019).

Sezgin, Nartgün, Ş. \& Kalay, M. (2014). Öğretmenlerin Örgütsel Destek, Örgütsel Özdeşleşme ile Örgütsel Sinizm Düzeylerine İlişkin Görüşleri. Journal of Turkish Studies, 9(2), 1361-1376.

Şantaş, F., Uğuluoğlu, Ö., Kandemir, A. \& Çelik Y. (2016). Sağlık Çalışanlarında Örgütsel Sinizm, İş Performansı ve Örgütsel Özdeşleşme Düzeyleri Arasındaki İlişkilerin İncelenmesi. Gazi Üniversitesi İktisadi ve İdari Bilimler Fakültesi Dergisi, 18(3), 867-886.

Şencan, H. (2005). Sosyal ve Davranışsal Ölçümlerde Güvenilirlik ve Geçerlilik. Ankara. Seçkin Yayınevi.

Tağraf, H. \& Bozkulak G. (2020). Mermer Sektörü Çalışanlarının Demografik Değişkenleri ile Örgütsel Sinizm Farklılıklarını İncelemeye Yönelik Bir Araştırma. Pearson Journal of Social Sciences \& Humanities, 5(9), 274-286.

Tajfel, H. (1982). Social Psychology of Intergroup Relations. Annual Review of Psychology, 33(1), 1-39.

Tak, B. \& Çiftçioğlu, A. (2009). Algılanan Örgütsel Prestij ile Örgütsel Bağl1lık ve Örgütsel Özdeşleşme Arasındaki İlişkilerin İncelenmesine Yönelik Bir Araştırma. Akdeniz I.I. B.F. Dergisi, 9(18), 100-116.

Taslak, S. \& Çiftçi, B. (Ed.). (2019). Postmodern Örgütlerde Güncel Davranışsal Konular Örnek Olay İncelemeleri. İstanbul. Beta Basım Yayım.

Taşlıyan, M., Hırlak, B. \& Çiftçi, G. E. (2016). Farklılık Yönetiminin Örgütsel Özdeşleşme Üzerine Etkisi: Akademik ve İdari Personel Üzerine Bir Araştırma. Elektronik Sosyal Bilimler Dergisi, 15(59), 1339-1359.

Tolman, E. C. (1943). Identification and The Post-War World. The Journal of Abnormal and Social Psychology, 38(2), 141-148.

Tuna, R., Eskin, Bacaksız, F., Harmanc1, Seren, A. K. (2018). The Effects of Organizational Identification and Organizational Cynicism on Employee Performance Among Nurses. International Journal of Caring Sciences, 11(3), 1707-1714.

Van, Dick, R. \& Wagner, U. (2002). Social Identification Among School Teachers: Dimensions, Foci, and Correlates. European Journal of Work and Organizational Psychology, 11(2), 129149.

Van, Knippenberg, D. \& Sleebos, E. (2006). Organizational Identification Versus Organizational Commitment: Self-Definition, Social Exchange, and Job Attitudes. Journal of Organizational Behavior, 27(5), 571-584.

Van, Knippenberg, D. \& Van, Schie, E. C. M. (2000). Foci and Correlates of Organizational Identification. Journal of Occupational and Organizational Psychology, 73(2), 137-147.

Walsh, K. \& Gordon, J. R. (2008). Creating an Individual Work Identity. Human Resource Management Review. 18(1), 46-61.

Whetten, D. A. \& Godfrey, P. C. (Ed.). (1998). Identity in Organizations: Building Theory Through Conversations. Thousand Oaks. Sage Publications.

Wilkerson, J. M., Evans, W. R. \& Davis, W. D. (2008). A Test of Coworkers' Influence on Organizational Cynicism, Badmouthing, and Organizational Citizenship Behavior. Journal of Applied Social Psychology, 38(9), 2273-2292.

Yakın, B., Sökmen, A. \& Bıyık, Y. (2017). Organizational Trust, Organizational Identification and Organizational Cynicism: A Researchon White Colors. International Journal of Business and Management Invention, 6(7), 72-78. 